\title{
What did we learn about ocean particle dynamics in the GEOSECS-JGOFS era?
}

Catherine Jeandel ${ }^{1}$, Michiel Rutgers van der Loeff ${ }^{2}$, Phoebe J. Lam ${ }^{3}$, Matthieu RoyBarman $^{4}$, Robert M. Sherrell ${ }^{5}$, Sven Kretschmer ${ }^{2}$, Chris German ${ }^{3}$ and Frank Dehairs ${ }^{6}$ 1- Observatoire Midi-Pyrénées-14, avenue Edouard Belin-31400-Toulouse-France Catherine.jeandel@legos.obs-mip.fr

2- Alfred-Wegener Institute for Polar and Marine Research, am Handelshafen 12, D-27570, Bremerhaven, Germany.

3- Woods Hole Oceanographic Institution, Woods Hole, MA 02543, USA

4- LSCE/IPSL Laboratoire CNRS/CEA/UVSQ, Domaine du CNRS, Bat 12 Avenue de la Terrasse, 91198 Gif-sur-Yvette Cedex, France 5-Institute of Marine and Coastal Sciences and Department of Earth and Planetary Sciences, Rutgers University, 71 Dudley Road New Brunswick, NJ 08901-8521 6- Vrije Universiteit Brussel, ESSC Research Group, Pleinlaan 2, 1050 Brussels, Belgium

\section{Key words: Historical review. Oceanic Particle distribution sources and sinks; GEOSECS; JGOFS; GEOTRACES. \\ * This article is dedicated to the memory of Devendra Lal (1929-2012) who wrote a seminal contribution to the study of "the oceanic microcosm of particles".}

Abstract

24 Particles determine the residence time of many dissolved elements in seawater. Although

a substantial number of field studies were conducted in the framework of major

oceanographic programs as GEOSECS and JGOFS, knowledge about particle dynamics

27 is still scarce. Moreover, the particulate trace metal behavior remains largely unknown.

28 The GEOSECS sampling strategy during the 1970's focused on large sections across

29 oceanic basins, where particles were collected by membrane filtration after Niskin bottle

30 sampling, biasing the sampling towards the small particle pool. Late in this period, the

31 first in situ pumps allowing large volume sampling were also developed. During the 1990's, JGOFS focused on the quantification of the "exported carbon flux" and its seasonal variability in representative biogeochemical provinces of the ocean, mostly using sediment trap deployments. Although scarce and discrete in time and space, these pioneering studies allowed an understanding of the basic fate of marine particles. This understanding improved considerably, especially when the analysis of oceanic tracers such as natural radionuclides allowed the first quantification of processes such as dissolved-particle exchange and particle settling velocities. Because the GEOTRACES 
39 program emphasizes the importance of collecting, characterizing and analyzing marine

40 particles, this paper reflects our present understanding of the sources, fate and sinks of

41 oceanic particles at the early stages of the program.

\section{Introduction}

The ocean contains $1.4 \times 10^{18}$ cubic meters of water and holds approximately $10^{10}$ metric 46 tons of solid material in the form of suspended particles that are present at an average

47 concentration in the deep sea ranging from 5 to $20 \mu \mathrm{g}$ per liter (Brewer et al., 1976;

48 Bishop and Fleisher, 1987; Sherrell and Boyle, 1992). Although not abundant, particles

49 act as an essential regulator of ocean chemistry because they determine the residence

50 time of many dissolved elements in seawater (Lal, 1977; Turekian, 1977). Vertical and

51 horizontal distributions of many trace elements and their isotopes (TEIs) are clearly

52 influenced by particle formation, remineralization, and transport. Because of their

53 importance, numerous studies during the past 50 years have focused on characterizing

54 these marine particles. In the 1970's, the Geochemical Ocean Sections study (GEOSECS;

55 Craig and Turekian, 1976) allowed a first description of the particle distribution in the

56 ocean, and mostly focused on suspended particles collected by filtration from Niskin-type

57 bottles. During those times, only a few pioneering studies attempting to characterize and

58 quantify particle fluxes were conducted (McCave, 1975; Honjo, 1976; Shanks and Trent,

59 1980). Nevertheless, these first results were invaluable in that i) they were the first

60 suggesting that vertical flux is dominated by rare large particles (McCave, 1975) and ii)

61 they guided the strategy of the Joint Global Ocean Flux Study (JGOFS) program (Fowler

62 and Knauer, 1986). However, laboratory and field technologies at that time were such

63 that measurements of TEIs in these particles with a good precision and resolution (spatial

64 as well as temporal) were difficult.

65 In the 1990's, the JGOFS program substantially increased our understanding of the

66 standing stock, vertical flux and fate of marine particles, with the focus largely on carbon

67 and associated nutrient cycles (Fasham et al., 2001). However, because of data scarcity

68 and the large variability of particle fluxes in time and space, the full characterization of

69 marine particle concentrations, flux, and composition was a difficult task, and remained

70 far from being achieved. The JGOFS era also suffered from a lack of methodologies for 
71 determining TEIs, which are extremely helpful for quantifying specific particle processes

72 in the water column. Although the analytical protocols for assessing some TEIs were

73 available and applied during some JGOFS research projects, they did not yet represent

74 the major research target. As a consequence, the global distribution of dissolved and

75 particulate TEIs is poorly known today. Because some TEIs are powerful tracers of

76 particle origin and processes (e.g. settling velocity, rates of dissolution, precipitation,

77 adsorption, and desorption) and some are essential micronutrients whose speciation in the

78 solid and dissolved phases is of prime importance for their bioavailability, there is an

79 urgent need to understand the global distribution of TEIs in the oceanic environment.

80 Filling this gap by investigating the sources, behavior and sinks of these TEIs is the main

81 goal of the GEOTRACES program (www.geotraces.org), which was developed following

82 the model of its "parent" program GEOSECS but with more emphasis on the collection,

83 observation, speciation and analysis of marine particles. As we enter the early stages of

84 the new GEOTRACES era, the present work reviews our understanding, informed by

85 GEOSECS and JGOFS, of the distribution of suspended and sinking marine particles of

86 both biogenic and abiogenic origin, as well as the role of these particles as regulators of

87 the marine biogeochemical cycles of TEIs. In addition to Anderson and Hayes'

88 introduction (this issue), this paper provides the historical context for this special issue

89 that proposes to browse the state of the art of our present knowledge on optically

90 characterizing (Boss et al., this issue), collecting (McDonnell et al., this issue), analyzing

91 (Lam et al., this issue) and modelling (Dutay et al., this issue; Jackson and Burd, this

92 issue) marine particles. The issue is concluded by Henderson and Marchal's comments

93 and perspectives.

Marine particles have two main origins, as illustrated in Figure 1.

99 (natural or anthropogenic, mineral or organic) into the ocean. These are transported via

100 the atmosphere (winds, rains), rivers (sedimentary discharge), or by lateral transport from

101 continental margin sediments. Before extensive damming, the annual solid flux

102 discharged by rivers to the oceans was of the order of $19 \times 10^{15} \mathrm{~g}$ (Peucker-Ehrenbrink, 
103 2009), which is 50 times the atmospheric flux (Jickells et al., 2005). Other particles are

104 extraterrestrial, such as micrometeorites (10 to $100 \mu \mathrm{m}$ in size) or cosmic dust that would

105 represent a flux of between 7 to $14 \times 10^{9} \mathrm{~g} / \mathrm{y}$ to the oceans (Johnson, 2001). Nano-

106 metric-sized (and highly magnetic) particles were also detected in the Greenland and

107 Antarctic ice caps and are identified as originating from atmospheric ablation of

108 meteorites and micrometeorites at high ( 100 km) altitude (Lanci et al., 2004; 2007).

109 Finally, hydrothermal vents also are a significant "external" source of particles for the

110 deep ocean. Particles from hydrothermal vents precipitate within the plume, forming fine

111 grained sulfide and oxide minerals that may be distributed over large regions of the deep

112 ocean (Mottl and McConachy, 1990; Feely et al., 1996; Sherrell et al., 2000; Tagliabue et

113 al., 2010).

114 Sources internal to the marine system: A huge quantity of marine particles is produced by

115 biological activity. Photoautotrophic plankton assimilates dissolved species (C, N, P, Si,

116 trace metals) and uses solar energy to synthesize organic matter, and specific groups,

117 including microheterotrophs, also secrete skeletal parts consisting of calcite, aragonite,

118 opal, or celestite. The annual flux of material so produced represents $\sim 60 \times 10^{15} \mathrm{~g} / \mathrm{y}$ of

119 organic carbon (Fasham et al., 2001). The magnitude of marine primary production is

120 similar to terrestrial primary production, but the standing stock of fixed organic carbon is

121 far less in the ocean than in terrestrial systems, resulting in much higher turnover rate of

122 carbon in the ocean. This high turnover rate has consequences for the cycling of TEIs

123 associated with this biogenic material. Other autotrophic organisms, such as nitrifiers, use

124 chemical energy, and are called chemolithotrophic (Griffith et al., 2012; Honjo et al.,

125 2012). These thrive throughout the oceanic water column and produce new biomass in-

126 situ. Autotrophic carbon fixation is the point of departure of the trophic chain whose life

127 and death cycle generates particles throughout the water column. Among the

128 heterotrophs, microzooplankton species, such as foraminifera, radiolarians, but also

129 larger multi-cellullar organisms such as salps and pteropods, represent a significant

130 portion of living biomass (Buitenhuis et al., 2013). Although less abundant than

131 phytoplanktonic organisms, they are important because of their role in packaging and

132 remineralization and for their potential as recorders, once incorporated in ocean

133 sediments, of past environmental conditions. In addition, diel vertical migration by 
134 mesozooplankton may represent a significant pathway of particle redistribution in the 135 mesopelagic zone, between water depths of about $100 \mathrm{~m}$ and $1000 \mathrm{~m}$ (Steinberg et al., 136 2008). Another source of particles in the upper water column is through spontaneous 137 aggregation of Dissolved Organic Matter (DOM) into larger particles, from the molecular

138 size up to a typical size of $4 \mu \mathrm{m}$, therefore becoming Particulate Organic Matter (POM).

139 These particles have been termed microgels (Verdugo, 2012). Barium sulfate, and

140 manganese and iron oxides and hydroxides are also known to precipitate within the water

141 column, incorporating other elements in the process, or scavenging trace elements by

142 adsorption or other particle surface phenomena (Krishnaswami et al., 1976a,b; Bishop

143 and Fleisher, 1987; Dehairs et al., 1990; Sherrell and Boyle, 1992; Paytan et al., 1993;

144 van Beek et al., 2007; van Beek et al., 2009).

145 Marine particles are often divided in 2 different types: small (micron-size) and slowly

146 sinking particles on one hand and large (> 50-100 micron-size) and rapidly sinking on the

147 other hand. The cut off is both poorly defined and somewhat arbitrary. However, it

148 corresponds to 2 modes of marine particle sampling: filtration on filters with (sub-)

149 micron size porosity for the small particles and collection in sediment trap and/or

150 filtration with large porosity for large particles. Hence, this operational definition is still

151 used in the GEOTRACES program.

2- Small suspended particles and TEI behavior

\section{2-1 Oceanic distribution of suspended particles}

157 Small particles $(0.2-53 \mu \mathrm{m})$ constitute the bulk of the particle standing stock in the ocean.

158 In the upper $1000 \mathrm{~m}$, particles $<53 \mu \mathrm{m}$ represent on average $\sim 80 \%$ of total suspended

159 particle mass (Bishop et al., 1977; Bishop et al., 1978; Bishop et al., 1980; Bishop et al.,

160 1985; Bishop et al., 1986; Lam and Bishop, 2007; Bishop and Wood, 2008). Their

161 amount and their large surface areas propel them as active players in the solution-solid

162 exchanges that impact TEI distribution (Krishnaswami et al., 1976; Anderson et al.,

163 1983a,b; Bishop and Fleisher, 1987; Sherrell and Boyle, 1992; Jeandel et al., 1995; Roy-

164 Barman et al., 1996). The vertical distribution of particles is characterized by a surface 
165 maximum sustained by primary production, which decreases very quickly in the upper

$166200 \mathrm{~m}$ and exponentially at greater depth (Figure 2). Some regions are also characterized

167 by strong intermediate (e.g., Iberian margin) and/or bottom (e.g., western boundary of the

168 Atlantic basin) nepheloid layers, resulting in profiles with surface and near-bottom

169 maxima and a clear-water minimum in the $2000-3000 \mathrm{~m}$ depth range as illustrated in

170 Figures 2 and 3 (Brewer et al., 1976; Biscaye and Eittreim, 1977).

171 Particles in the upper $1000 \mathrm{~m}$, especially in open ocean areas, are produced internally in

172 the marine system and are composed primarily of biogenic materials: particulate organic

173 matter, $\mathrm{CaCO}_{3}$, and biogenic silica. Particles in regions with high external inputs, such as

174 the North Atlantic and the Mediterranean Sea with their high dust deposition and high

175 sedimentary inputs, have a composition characterized by a higher fraction of lithogenic

176 material -which could reach $70 \%$ of the total mass (Roy-Barman et al., 2009)-

177 particularly at depths where biogenic matter is being remineralized (POM) or is

178 dissolving (biogenic silica or $\mathrm{CaCO}_{3}$ ). A relatively high fraction of mineral particles is

179 also found in benthic nepheloid layers, where surface sediment particles that are

180 relatively poor in biogenic components are resuspended into bottom waters (Figure 3;

181 Gardner et al., 1983).

182 Before the advent of the GEOTRACES program, full water column profiles of trace

183 metal and isotopic composition of suspended particles were measured in only a few

184 locations. The trace element composition (including Al, Mn, Fe, Co, Ni, Cu, Zn, Cd and

$185 \mathrm{~Pb}$ ) of suspended particles was measured at BATS in the Sargasso Sea (Sherrell and

186 Boyle, 1992), in the North Pacific subtropical gyre (Bruland et al., 1994), and off Point

187 Conception (CA) in the Northeast Pacific (Sherrell et al., 1998). The acetic acid leachable

188 and refractory fractions of particulate iron, manganese, and aluminum have been

189 measured in the North Pacific (Orians and Bruland, 1986; Landing and Bruland, 1987).

190 During the GEOSECS Atlantic cruises in the seventies, full water column data for a

191 whole suite of trace and minor elements were obtained by neutron activation of total

192 suspended matter (Ba, Ti, Sr, Mn, Mg, Cu, V, Al, Ca, La, Au, Hg, Cr, Sb, Sc, Fe, Zn, Co;

193 Peter Brewer, unpublished results). These data are currently being compared to those

194 obtained as part of the early GEOTRACES cruises. Such quality controlled data will be

195 further stored in the GEOTRACES Data Center, under the label "historical data". 


\section{2-2 Role of suspended particles in oceanic processes}

199 Once we understand what drives the dissolved/colloidal/particulate partitioning of a

200 tracer, this information can then be used in turn to trace oceanic processes. Non-

201 exhaustively, we can cite:

202 - Dissolved and particulate ${ }^{230} \mathrm{Th}$ and ${ }^{231} \mathrm{~Pa}$ activity distributions provide an efficient tool

203 for estimating apparent particle settling velocities and therefore residence times in the

204 water column (Krishnaswami et al., 1976; Bacon and Anderson, 1982; Bacon et al.,

205 1985; Roy-Barman et al., 1996). The apparent settling velocity is the net effect of all

206 processes that are described in Figure 4. We acknowledge that reducing the particle

207 distribution in 2 categories only as represented in Figure 4 are simplified views of this

208 distribution, driven partly by sampling and analytical logistics. However, a two particle

209 class model captures two of the most important particle processes that are of interest here:

210 scavenging and sinking (see also McDonnell et al., this issue). The particle residence

211 times deduced from these radionuclide distributions can therefore be applied to other

212 poorly soluble TEIs.

$213-\Delta^{14} \mathrm{C}, \delta^{13} \mathrm{C}$ and $\delta^{15} \mathrm{~N}$ distributions allow the identification of terrestrial versus marine

214 origin of organic matter, episodes of re-suspension of shelf or slope organic matter,

215 penetration of atmospheric nitrogen and carbon and/or oxidative processes (Williams et

216 al., 1992; Mollenhauer et al., 2003; Mollenhauer et al., 2005)

217 - Biologically driven barite precipitation in the surface or sub-surface waters provide a

218 good tool for surface productivity reconstruction, in the modern as well as in the past

219 ocean (Dehairs et al., 1991; Dehairs et al., 1992; Jeandel et al., 2000; Cardinal et al.,

220 2001; Jacquet et al., 2008; Sternberg et al., 2008; Paytan et al., 1993; van Beek and

221 Reyss, 2001; van Beek et al., 2002).

222 - Rare earth elements (REEs) and Nd isotopes trace the origin of suspended material as

223 well as dissolved-particle exchanges in the water column (Jeandel et al., 1995;

224 Tachikawa et al., 1999a; Kuss et al., 2001).

225 - Manganese and iron are redox sensitive and less soluble when oxidized. In the surface

226 waters, photochemistry can efficiently change the speciation of these tracers and 
227 therefore their distributions. In the water column, co-precipitation and/or adsorption of

228 TEIs on $\mathrm{Mn}$ and $\mathrm{Fe}$ oxyhydroxides result in removal of elements such as $\mathrm{Co}, \mathrm{Cu}, \mathrm{Ni}, \mathrm{Zn}$,

229 Th but also REEs (Anderson et al., 1983a, b; Landing and Bruland, 1987; Sherrell and

230 Boyle, 1992; Moffett and Ho, 1996; Cardinal et al., 2001; Roy-Barman et al., 2009; Kuss

231 et al., 1999; Tachikawa et al., 1999b).

232 - Particle formation above submarine hydrothermal vents plays an important role in

233 modifying the gross flux from hydrothermal systems to the oceans. Approximately $50 \%$

234 of the dissolved Fe released from a high-temperature vent is predicted to be precipitated

235 in the form of polymetallic sulfides in buoyant hydrothermal plumes within minutes of

236 emission from the seafloor (Rudnicki and Elderfield, 1993). The remaining Fe

237 precipitates more slowly, in the form of Fe-oxyhydroxides (Sherrell et al., 2000) which

238 can significantly impact the scavenging of trace elements and isotopes (oxyanions, $\mathrm{Be}, \mathrm{Y}$,

239 REE, Th, Pa) from the water column (Michard et al., 1983; Lilley et al., 1993). This

240 hydrothermal scavenging can be so pronounced as to match the boundary scavenging

241 effects seen at high productivity ocean margins (German et al., 1997). Most prior works

242 assumed that hydrothermal plume particle formation is an inorganic process, but recent

243 studies have shown that significant concentrations of organic carbon are incorporated into

244 hydrothermal particles (Bennett et al., 2011; Toner et al., 2009) and further that the

245 formation of these particulate phases may be microbially mediated (Sylvan et al., 2012).

\section{3- The role of sinking particles in TEI cycling}

249 Large particles (> $53 \mu \mathrm{m}$, under typical methodological size fractionation) make up most

250 of the vertical flux and therefore contribute to the sequestration of most elements in the

251 deep ocean. The size criterion for separating suspended and sinking particles is more an

252 operational definition than a biogeochemical one: small and dense particles (as fecal

253 pellets for example) can sink faster than large fluffy aggregates (McCave, 1975). Indeed,

254 in the ocean, particle distribution follows a continuous spectrum whose sinking rates do

255 not necessarily increase monotonically with size (McDonnell and Buesseler, 2010;

256 McDonnell et al, this issue). 
257 There are two approaches to sampling sinking particles to study TEI cycling: 1) sizefractionated filtration, which separates the particle pool into an operationally defined "suspended" size class (e.g. $<53 \mu \mathrm{m}$ ) and a "sinking" size class (e.g. $>53 \mu \mathrm{m}$ ), and 2)

260 direct collection of sinking particles of various sizes in sediment traps (Honjo, 1978;

261 McDonnell et al., this issue). In the first approach, geochemists analyze the TEI contents

262 of the different fractions, providing "state variables" of the systems to the modelers (Lam

263 et al., this issue; Dutay et al., 2009; Dutay et al., this issue). Despite this crude and

264 operational separation of the particle pool, thorium isotope distribution studies have

265 nonetheless shown that small and large particles exchange with each other throughout the

266 water column, as well as with the dissolved phases. This has yielded the conceptual

267 model for particle dynamics first proposed by Bacon et al. (1985) and represented in

268 Figure 4.

269 In addition to thorium isotopes, measurements of the size-fractionated concentrations of

270 other TEIs such as manganese, neodymium and barium have also yielded insights into

271 particle aggregation and disaggregation processes (Bishop and Fleisher, 1987; Jeandel et

272 al., 1995; Bishop and Wood, 2008).

273 In the second approach, sinking particles collected from sediment traps are analyzed

274 directly. The majority of sediment trap studies have had as their goal a better

275 understanding of the biological pump. As such, sediment trap studies most frequently

276 report measurements of particulate organic carbon (POC) and particle mass, and often

277 also major particle phases such as $\mathrm{CaCO}_{3}$, biogenic silica, and lithogenic material, but

278 TEI measurements are much more rare (Brewer et al., 1980).

279 Compilations of the major phase composition ( $\mathrm{POM}, \mathrm{CaCO}_{3}$, biogenic $\mathrm{Si}$, lithogenics) of

280 sinking particles from bottom-tethered sediment traps during the JGOFS era have been

281 published (Antia et al., 2001; Armstrong et al., 2002; François et al., 2002; Klaas and

282 Archer, 2002; Lutz et al., 2007; Honjo et al., 2008; Honjo et al., 2010) and show a wide

283 geographic range in the magnitude and efficiency of POC flux to depth. Analysis of a

284 compilation of $>53 \mu \mathrm{m} \mathrm{POC}, \mathrm{CaCO}_{3}$ and biogenic $\mathrm{Si}$ concentrations also show wide

285 geographic and temporal range in the transfer of POC to depth (Lam et al., 2011).

286 Several studies have noted correlations between the fluxes of $\mathrm{POC}$ and $\mathrm{CaCO}_{3}$ in deep

287 sediment traps (>1000 m) and have sparked numerous other studies as to the processes 
288 behind this correlation. In contrast, the fraction of net primary production that is

289 exported from the euphotic zone is often correlated with the abundance of large

290 phytoplankton taxa, especially diatoms (Buesseler, 1991; Buesseler et al., 2007a; Guidi et

291 al., 2009; Honda and Watanabe, 2010), illustrating that controls on shallow export flux

292 may be decoupled from controls on deep POC flux (François et al., 2002; Lomas et al.,

293 2010). Several time-series stations such as Bermuda Atlantic Time Series Study

294 (http://bats.bios.edu), Hawaii Ocean Time series in the Pacific

295 (http://hahana.soest.hawaii.edu/hot/hot-dogs/interface.html), DYFAMED time series in

296 the Mediterranean Sea (http://www.eurosites.info/dyfamed.php; Miquel et al., 2011) and

297 ESTOC time series north of the Canary Islands (Neuer et al., 1997; Patsch et al., 2002),

298 as well as dedicated programs such as EUMELI (Bory et al., 2001), VERTIGO

299 (Buesseler et al., 2007a; Lamborg et al., 2008), and MedFlux (Lee et al., 2009) have also

300 shown wide ranging temporal variability in particle flux and composition. Even though

301 there are relatively few studies that have measured TEIs directly on sinking particles

302 (Huang and Conte, 2009), the wide geographic and temporal variability in particle

303 sinking flux implies that the sinks of particle-reactive TEIs will experience similar

304 variability (Antia et al., 2001; Scholten et al., 2001).

305 At some of the sites listed above and elsewhere, TEIs were measured in the trapped

306 material too. Most of these works used U-Th series to reconstruct or calibrate POC

307 fluxes (Cochran et al., 1993; Sarin et al., 2000; Roy-Barman et al., 2005; Stewart et al.,

308 2007; Trull et al., 2008; Cochran et al., 2009; Roy-Barman et al., 2009). Others used

309 stable ${ }^{13} \mathrm{C}$ and ${ }^{15} \mathrm{~N}$ or barite to differentiate biogeochemical cycles (Jeandel et al., 2000;

310 Lourey et al., 2004; Casciotti et al., 2008), and a few have used REE and radiogenic

311 isotope data to trace the origin of the particles (Jeandel et al., 1995; Tachikawa et al.,

312 1997; Chavagnac et al., 2008). The pioneer VERTEX program allowed investigations of

313 the major and trace element composition of sinking particles from the Pacific (Knauer $e t$

314 al., 1979; Fowler and Knauer, 1986) but the measurement of contamination-prone TEIs

315 in sediment trap samples has only become more common recently (Kuss and Kremling,

316 1999; Frew et al., 2006; Lamborg et al., 2008; Bowie et al., 2009; Ho et al., 2010; Ho et

$317 a l ., 2011)$. When studying fluxes of trace elements collected by sediment traps, one must 
318 be aware of the tendency for TEIs to dissolve into supernatant solutions (Kumar et al., 319 1996).

323 The chemical behavior of particle-reactive metals such as Th, Pa, Nd and other REE is

324 often characterized by a partition coefficient $K_{d}$ between seawater and marine particles 325 defined as:

$326 K_{d}=\frac{\text { mass of porticulate tracer per mass of particles }}{\text { mass of dissolved tracer per volwe of seawater }}$

328 To first order, $K_{d}$ for a given element is expected to depend of the chemical bulk

329 composition of the marine particles. Several approaches have been used to determine the

330 relationship between $K_{d}$ and particle composition.

331 For elements having isotopes produced in situ such as $\mathrm{Th}$ and $\mathrm{Pa}$, two methods have been

332 used: 1) correlation of isotopes produced in situ with the main components of sinking

333 marine particles collected by sediment traps, and 2) sorption experiments using natural or

334 artificial seawater and particles. Sediment trap analyses have shown correlations between

335 radioisotopes and inorganic phases, but fortuitous correlations between components have

336 produced conflicting interpretations (Chase et al., 2002; Luo and $\mathrm{Ku}, 2004$; Roy-Barman

337 et al., 2005; Roy-Barman et al., 2009). Some of these fortuitous correlations could be

338 avoided by directly studying small filtered particles, because they dominate the solid

339 surface area per volume and thus are more likely to adsorb tracers from seawater. This

340 would require that the total mass and the major components of filtered particles be

341 determined (Lam et al., this issue). While focus has mainly been on the impact of major

342 components on $K_{d}$ (see references above), minor phases such as Mn oxides could play a

343 significant role in the scavenging of Th (Roy-Barman et al., 2009) and $\mathrm{Pa}$ (Anderson et

$344 a l ., 1983 a, b)$ in deep waters. Sorption experiments have shown a relatively low affinity of

345 Th for inorganic phases and a high affinity for organic compounds (Santschi et al., 2006).

346 These results are consistent with ${ }^{234}$ Th scavenging in shallow waters, but they fail to 
347 explain the correlations between ${ }^{230} \mathrm{Th}$ and inorganic phases (carbonate, lithogenic or $\mathrm{Mn}$

348 oxides, see previous paragraph) observed in sediment trap data.

349 For elements derived from continental erosion, such as Neodymium (Nd) or Hafnium

350 (Hf), with no in situ sources of isotopes, the authigenic fraction of the elements in

351 particles can be determined by subtraction of the lithogenic fraction (Kuss et al., 2001,

352 Garcia-Solsona et al., 2014), chemical leaching or isotopic balance (Tachikawa et al.,

353 1999b; Tachikawa et al., 2004). These methods do not necessarily give consistent results.

354 In the case of leaching, the selective dissolution of authigenic phases, without

355 contamination from other phases, remains to be demonstrated. More importantly, re-

356 adsorption of leached TEIs to refractory phases, and the incomplete removal of colloidal

357 materials mobilized during leaching procedures, can confound the interpretation of the

358 original carrier of TEIs (Lam et al., this issue). Consequently, an approach based on

359 isotopic mass balance or on the statistical correlation among end member particulate

360 phases is preferred.

361 Recently, physical separations have brought new insights by partially isolating and

362 enriching some carriers (Kretschmer et al., 2010; 2011). The development of the analysis

363 of individual particles allows the unambiguous determination of some carriers (Roy-

364 Barman, pers. comm.). Particle observation should be systematically coupled to particle

365 analysis (Lam et al., this issue). Besides methodological aspects, fundamental aspects of

366 the tracer's behavior must be addressed:

367 - Possible disequilibrium between particles and seawater (Coppola et al., 2006;

368 Venchiarutti et al., 2011).

$369-$ The role of the colloidal phase for both organic and inorganic compounds.

$370-$ The impact of mineralization on the particle composition and $K_{d}$.

371 The present uncertainties on the $K_{d}$ of $\mathrm{Pa}$, Th and $\mathrm{Nd}$ have direct impacts on our

372 understanding of the distribution of these tracers in the ocean. For example, several

373 models "successfully" represent the Nd concentration and isotopic composition in the

374 ocean but in fact use different particle models (particle mineralization or boundary

375 exchange) and $K_{d}$ (equilibrium versus adsorption-desorption) that are adjusted to

376 eventually match the data (synthesis in Rempfer et al., 2011, 2012; Arsouze et al., 2009). 
377 More dissolved and particle data from representative oceanic regimes are required to

378 constrain models, one of the main missions of GEOTRACES.

\section{5- Benthic and Intermediate Nepheloid Layers and their impacts on TEI}

\section{distribution}

Benthic Nepheloid Layers (BNLs) occur wherever bottom currents interact with the (deep) sea floor (Biscaye and Eittreim, 1977, McCave et al., 2001). In the discussion of the effect of a BNL on the distribution of TEIs, we can distinguish the effects at two spatial scales: (i) the effects on a local scale, like those related to currents characterized by high level of eddy kinetic energy and to currents over seamounts (Turnewitsch et al.,

\section{5-1 Local re-suspension}

The generation of a BNL and the distribution and size spectra of particles have been

394 described by McCave (1984, 1986, 2001). Vertical mixing in bottom layers was studied during GEOSECS with ${ }^{222} \mathrm{Rn}$ (Sarmiento et al., 1976). The vertical extent of BNLs is enhanced by the detachment of bottom mixed layers (Armi and D'Asaro, 1980). If surface sediments are in adsorption equilibrium with the bottom water, re-suspension need not

398 change this equilibrium. However, there are cases in which interaction between re-

399 suspension and bioturbation can change the distribution of dissolved components in the

400 BNL relative to the water layer just above the BNL: 1) if the tracer decays within the

401 bioturbated zone, or 2) if $K_{d}$ changes as a result of diagenetic changes (e.g. $\mathrm{MnO}_{2}$

402 enrichment) or particle dynamics like aggregation-disaggregation (Rutgers van der Loeff

403 and Boudreau, 1997). There is no indication that the particle concentration has an effect

404 on the $K_{d}$ in the BNL (Honeyman et al., 1988).

405 For short-lived radionuclides like ${ }^{234} \mathrm{Th}$ and ${ }^{210} \mathrm{~Pb}$, condition (1) above is clearly met.

406 Profiles of dissolved ${ }^{234} \mathrm{Th}$ provide clear evidence for enhanced removal of dissolved

407 TEIs from bottom waters in the presence of nepheloid layers (Bacon and Rutgers van der 
408 Loeff, 1989). Enhanced removal of particle-reactive TEIs near the sea bed has been

409 evident since GEOSECS-era studies of ${ }^{210} \mathrm{~Pb}$ (Craig et al., 1973), and the concept of

410 bottom scavenging has been reintroduced recently through the study of ${ }^{230} \mathrm{Th}$ (Okubo et

411 al., 2012). However, developing a direct link between sediment re-suspension and

412 enhanced removal of TEIs near the sea bed will require joint research on particles as well

413 as on the distribution of dissolved TEIs.

414

$415 \quad$ 5-2 Long-range transport in the BNL

416

417 Strong bottom currents occur along the western boundaries of the ocean basins (Warren,

418 1981), and deep wind and buoyancy-driven currents such as the Antarctic Circumpolar

419 Current can reach abyssal depths (e.g. in the Drake Passage; Renault et al., 2011).

420 Through re-suspension or, rather, selective deposition, these currents can maintain high

421 loads of suspended sediments. In the BNL, particles may be transported over large

422 distances as shown for clay minerals (Griffin et al., 1968; Petschik et al., 1996;

423 Diekmann et al., 2004). This means that particles are not only redistributed locally

424 (winnowing and focusing) but also transported between areas with widely different local 425 sediment compositions.

\section{5-3 TEI fractionation}

429 The composition of material suspended in the BNL is different from that in the clear 430 water above it. Grain size fractionation has been described in detail by the studies of I.

431 McCave (Mc Cave, 2001). The possible effect of grain size fractionation on the isotopic 432 composition of deposited sediments was studied by Kretschmer et al. (2010; 2011) who 433 found that :

434 - ${ }^{230} \mathrm{Th},{ }^{231} \mathrm{~Pa}$ and ${ }^{10} \mathrm{Be}$ adsorb preferentially onto the smallest grain sizes

435 - ${ }^{231} \mathrm{~Pa} /{ }^{230} \mathrm{Th}$ and ${ }^{10} \mathrm{Be} /{ }^{230} \mathrm{Th}$ ratios are enhanced in a slowly settling pure opal 436 fraction

437 - Settling rate fractionation during sediment focusing causes an increase in the bulk $438{ }^{230} \mathrm{Th}$ concentration and in the ${ }^{231} \mathrm{~Pa} /{ }^{230} \mathrm{Th}$ ratio. 
$30 / 12 / 201419: 56$

\section{5-4 Intermediate Nepheloid Layers}

442 There are many examples of Intermediate Nepheloid Layers (INLs) caused by the 443 detachment of a BNL at the shelf break and other breaks in slope where internal tidal 444 energy is focused, followed by offshore advection (McCave et al., 2001). It would be 445 important to study the link between the dispersal of particulate (INLs) and dissolved

446 tracer signals from the shelf (e.g. Fe and Mn releases, ${ }^{210} \mathrm{~Pb}$ removal, Nd isotope

447 exchange (Sherrell et al., 1998; Lacan and Jeandel, 2005; Lam and Bishop, 2008). The

448 particulate signal disappears by sinking and aggregate formation (Clegg and Whitfield,

449 1990, 1991; Karakas et al., 2006; 2009). The time scale of distribution of dissolved shelf 450 inputs can be studied with short lived Ra isotopes and ${ }^{228} \mathrm{Th}$.

\section{6- "Historical" understanding of particle dynamics and perspectives}

454 Despite its fundamental role in controlling the chemical composition of the ocean

455 (Goldberg, 1954; Turekian, 1977) and the different cruises conducted in the 70s and 80s, 456 the "oceanic microcosm of particles"-as christened by Lal (1977) - is far from being 457 understood yet. In addition, sampling strategies and scientific focus differed between the 458 GEOSECS and JGOFS programs. GEOSECS carried out large sections across the 459 oceanic basins, where particles were collected by membrane filtration after bottle 460 sampling, biasing the sampling towards the small particle pool. Analyses mostly 461 informed us about the distribution of particle concentrations (mass/L), their major 462 element compositions, as well as a few tracers and selected morphological and qualitative 463 composition descriptions, thanks to the first Scanning Electron Microscopy (SEM)

464 analyses. Subsequent box and one-dimensional (vertical) models described the different 465 fluxes exchanged in and out the oceanic system as well as along the water column. These 466 pioneering efforts led to the emergence of the fundamental notion of "reversible 467 scavenging" (Brewer et al., 1976; Krishnaswami et al., 1976; Lal, 1980; Nozaki et al., 468 1981; Bacon and Anderson, 1982; Anderson et al., 1983a). They also highlighted the role 
469 of "particle-rich" continental margins on the distribution of ocean tracers (Anderson and

470 Henderson, 2003; Jeandel et al., 2011).

471 JGOFS identified representative biogeochemical provinces of the ocean, where most of

472 the work was dedicated to the quantification of the "exported carbon flux" and its

473 seasonal variability (Fasham et al., 2001). Except for rare studies just prior to JGOFS

474 that conducted small particle sampling and deployed the first in situ pumps allowing

475 large volume filtration (Krishnaswami et al., 1976; Bacon and Anderson, 1982; Bishop et

476 al., 1985; Rutgers van der Loeff and Berger, 1993; Jeandel et al., 1995; Tachikawa et al.,

477 1999b), most of the field work conducted during JGOFS deployed moored and (or)

478 drifting sediment traps. TEIs were barely measured, except perhaps ${ }^{234} \mathrm{Th}$ and ${ }^{230} \mathrm{Th}$

479 isotopes, which were recognized as useful for POC flux calibration and quantification.

480 Resulting models describe the exported carbon flux as it was related to the surface

481 nutrient distribution using 1D and 3D models coupling physics and biology (Bopp et al.,

482 2002). Most of the particle models developed in the late 80s and in the 90 s are

483 mechanistic and abiotic (Dutay et al., this issue; Burd and Jackson, 2009; Jackson and

484 Burd, this issue). Early models coupled particle dynamics to ocean circulation in an

485 OGCM, although processes describing the particle behavior in such 3D dynamical

486 models remained one-dimensional (Henderson and Maier-Reimer, 2002; Gehlen et al.,

487 2003; Gehlen et al., 2006; Arsouze et al., 2009; Dutay et al., 2009; Rempfer et al., 2011).

\section{Conclusion}

491 At the beginning of the GEOTRACES program, we have to admit that our collective

492 understanding of the processes governing the solution-particle exchange has made little

493 progress in the preceding two decades. Key questions remain:

494 i) What are the affinities of the various TEIs for the different particulate phases

495 (Rutgers van der Loeff and Berger, 1993; Chase et al., 2002; Anderson and Henderson,

496 2003; Geibert and Usbeck, 2004; Luo and Ku, 2004; Roy-Barman et al., 2005; Santschi

497 et al., 2006; Roy-Barman et al., 2009)? 
498 ii) What is the role of remineralization in the mesopelagic zone (Dehairs et al., 1995;

499 Dehairs et al., 1997; Frew et al., 2006; Boyd and Trull, 2007; Buesseler et al., 2007b;

500 Dehairs et al., 2008)?

501 iii) What is the impact of sediment diagenesis on the composition of resuspended

502 particles and on their ability to scavenge additional TEIs, despite having previously

503 equilibrated with dissolved species in the water column (Kretschmer et al., 2010;

504 Kretschmer et al., 2011)?

505 iv) What are the roles of the BNLs and INLs on the boundary scavenging and boundary

506 exchange processes (Bacon et al., 1988; Roy-Barman et al., 2005; Roy-Barman et al.,

507 2009)?

508 v) What is the importance of other surface processes like chemoautotrophy as a source of

509 particles in the deep ocean (Honjo et al., 2012)?

510 Answers to these questions can be provided by the GEOTRACES program with the

511 implementation of a comprehensive sampling and analytical strategies (pumps, optics,

512 observations and analysis of particles, see McDonnell et al., this issue; Boss et al., this

513 issue, Lam et al., this issue...), designed to elucidate the role of particles as agents of

514 supply and removal of TEIs in the ocean. There is an urgent need for re-focusing on

515 discrete particle composition, speciation and morphologies.

\section{Acknowledgements}

518 This paper arose from a workshop that was co-sponsored by ESF COST Action ES0801,

519 "The ocean chemistry of bioactive trace elements and paleoproxies". Additional support

520 for that workshop came from SCOR, through support to SCOR from the U.S. National

521 Science Foundation (Grant OCE- 0938349 and OCE-1243377). Support for PJL from

522 U.S. NSF grant OCE-0963026. The authors deeply thank the AE and two anonymous

523 reviewers for their fruitful comments. 


\section{References}

Anderson, R. F., Bacon, M. P., Brewer, P. G., 1983a. Removal of ${ }^{230} \mathrm{Th}$ and ${ }^{231} \mathrm{~Pa}$ at ocean margins. Earth and Planetary Science Letters 66(1-3), 73-90.

Anderson, R. F., Bacon, M. P., Brewer, P. G., 1983b. Removal of ${ }^{230}$ Th and ${ }^{231} \mathrm{~Pa}$ from the open ocean. Earth and Planetary Science Letters 62(1), 7-23.

Anderson, R. F., Henderson, G., 2003. The U-series toolbox for paleoceanography, Reviews in Mineralogy and Geochemistry 52, 493-531.

Antia, A. N., Koeve, W., Fischer, G., Blanz, T., Schulz-Bull, D., Scholten, J., Neuer, S., Kremling, K., Kuss, J., Peinert, R., Hebbeln, D., Bathmann, U., Conte, M., Fehner, U., Zeitzschel, B., 2001. Basin-wide particulate carbon flux in the Atlantic Ocean: Regional export patterns and potential for atmospheric $\mathrm{CO}_{2}$ sequestration. Global Biogeochemical Cycles 15(4), 845-862.

Armi, L., D'Asaro, E., 1980. Flow structures in the benthic ocean. Journal of Geophysical Research 85, 469-484.

Armstrong, R. A., Lee, C., Hedges, J. I., Honjo, S., Wakeham, S. G., 2002. A new, mechanistic model for organic carbon fluxes in the ocean based on the quantitative association of POC with ballast minerals. Deep-Sea Research Part IITopical Studies in Oceanography 49 (1-3), 219-236.

Arsouze, T., Dutay, J. C., Lacan, F., Jeandel, C., 2009. Reconstructing the Nd oceanic cycle using a coupled dynamical - biogeochemical model. Biogeosciences 6 (12), 2829-2846.

Bacon, M. P., Anderson, R. F., 1982. Distribution of Thorium Isotopes between dissolved and particulate forms in the deep-sea. Journal of Geophysical Research-Oceans and Atmospheres 87(NC3), 2045-2056.

Bacon, M. P., Belastock, R. A., Tecotzky, M., Turekian, K. K., Spencer, D. W., 1988. ${ }^{210} \mathrm{~Pb}$ and ${ }^{210} \mathrm{Po}$ in ocean water profiles of the continental-shelf and slope south of New-England. Continental Shelf Research 8 (5-7), 841-853.

Bacon, M. P., Huh, C.-H., Fleer, A. P., Deuser, W. G., 1985. Seasonality in the flux of natural radionuclides and plutonium in the deep Sargasso Sea. Deep Sea Research 32, 273-286.

Bacon, M. P., Rutgers van der Loeff, M. M., 1989. Removal of ${ }^{234}$ Th by scavenging in the bottom nepheloid layer of the ocean. Earth and Planetary Science Letters 92, 157-164.

Bennett, S. A., Statham, P. J., Green, D. R. H., Le Bris, N., McDermott, J. M., Prado, F., Rouxel, O. J., Von Damm, K., German, C. R., 2011. Dissolved and particulate organic carbon in hydrothermal plumes from the East Pacific Rise, 9 degrees 50 ' N. Deep-Sea Research Part I-Oceanographic Research Papers 58(9), 922-931.

Biscaye, P. E., Eittreim, S. L., 1977. Suspended particulate loads and transport in the nepheloid layer of the abyssal Atlantic Ocean. Marine Geology 23, 155-172.

Bishop, J.K.B., Collier, R.W., Kettens, D.R., Edmond, J.M., 1980. The Chemistry, Biology, and Vertical Flux of Particulate Matter from the Upper 1500m of the Panama Basin. Deep-Sea Research Part a-Oceanographic Research Papers, 27, 615-640. 
604

605

606

607

608

609

610
Bishop, J.K.B., Edmond, J.M., Ketten, D.R., Bacon, M.P., Silker, W.B., 1977. Chemistry, Biology, and Vertical Flux of Particulate Matter from Upper $400 \mathrm{~m}$ of Equatorial Atlantic Ocean. Deep-Sea Research, 24, 511-548.

Bishop, J. K. B., Fleisher, M. Q., 1987. Particulate manganese dynamics in the Gulf Stream warm-core rings and surrounding waters of the N.W. Atlantic. Geochimica et Cosmochimica Acta 51, 2807-2825.

Bishop, J.K.B., Ketten, D.R., Edmond, J.M., 1978. Chemistry, Biology and Vertical Flux of Particulate Matter from the Upper $400 \mathrm{~m}$ of the Cape Basin in the Southeast Atlantic Ocean. Deep-Sea Research, 25, 1121-1161.

Bishop, J. K. B., Schupack, D., Sherrell, R. M., Conte, M. H., 1985. A Multiple Unit Large Volume in-situ Filtration System (MULVFS) for sampling oceanic particulate matter in mesoscale environments. In: Mapping strategies in Chemical Oceanography, ed. A. Zirino, 155-175.

Bishop, J.K.B., Stepien, J.C., Wiebe, P.H., 1986. Particulate Matter Distributions, Chemistry and Flux in the Panama Basin - Response to Environmental Forcing. Progress in Oceanography, 17, 1-59.

Bishop, J. K. B., Wood, T. J., 2008. Particulate matter chemistry and dynamics in the twilight zone at VERTIGO ALOHA and K2 sites. Deep Sea Research Part I: Oceanographic Research Papers 55, 1684-1706.

Bopp, L., Le Quéré, C., Heimann, M., Manning, A. C., Monfray, P., 2002. Climateinduced oceanic oxygen fluxes: Implications for the contemporary carbon budget. Global Biogeochemical Cycles 16(2), 6-1-6-13.

Bory, A., Jeandel, C., Leblond, N., Vangriesheim, A., Khripounoff, A., Beaufort, L., Rabouille, C., Nicolas, E., Tachikawa, K., Etcheber, H., Buat-Ménard, P., 2001. Downward particle fluxes within different productivity regimes off the Mauritanian upwelling zone (EUMELI program). Deep-Sea Research Part IOceanographic Research Papers 48(10), 2251-2282.

Boss E., Guidi, L., Richardson, M.J., Stemmann, L., Gardner, W., Bishop, J.K.B, Anderson, R.F. and Sherrell, R. This issue, Optical techniques for in-situ characterization of particles pertinent 1 to GEOTRACES. Progress in Oceanography.

Bowie, A. R., Lannuzel, D., Remenyi, T. A., Wagener, T., Lam, P. J., Boyd, P. W., Guieu, C., Townsend, A. T., Trull, T. W., 2009. Biogeochemical iron budgets of the Southern Ocean south of Australia: Decoupling of iron and nutrient cycles in the subantarctic zone by the summertime supply. Global Biogeochemical Cycles 23, GB4034.

Boyd, P. W., Trull, T. W., 2007. Understanding the export of biogenic particles in oceanic waters: Is there consensus? Progress in Oceanography 72(4), 276-312.

Brewer, P. G., Spencer, D. W., Biscaye, P. E., Hanley, A., Sachs, P. L., Smith, C. L., Kadar, S., Fredericks, J., 1976. The distribution of particulate matter in the Atlantic Ocean. Earth and Planetary Science Letters 32, 393-402.

Brewer, P.W., Nozaki Y., Spencer, D.W., and Fleer, P.A, 1980. Sediment trap experiments in the deep North Atlantic: isotopic and elemental fluxes. Journal of Marine Research 38, 703-728.

Bruland, K. W., Orians, K. J., Cowen, J. P., 1994. Reactive trace metals in the stratified central North Pacific. Geochimica et Cosmochimica Acta 58, 3171-3182. 
652

653

654

655

656

657

658

659

660

Buesseler, K. O., 1991. Do upper-ocean sediment traps provide an accurate record of particle flux? Nature 353, 420-423.

Buesseler, K. O., Antia, A. N., Chen, M., Fowler, S.W., Gardner, W.D., Gustafsson, O., Harada, K., Michaels, A.F., Rutgers van der Loeff, M.M., Sarin, M., Steinberg, D. K., Trull, T.W., 2007a. An assessment of the use of sediment traps for estimating upper ocean particle fluxes. Journal of Marine Research 65(3), 345-416.

Buesseler, K. O., Lamborg, C. H., Boyd, P. W., Lam, P.J., Trull, T.W., Bidigare, R.R., Bishop, J. K.B., Casciotti, K.L., Dehairs, F., Elskens, M., Honda, M., Karl, D. M., Siegel, D.A., Silver, M. W., Steinberg, D. K., Valdes, J., Van Mooy, B., Wilson, S., 2007b. Revisiting carbon flux through the ocean's twilight zone. Science 316, 567-570.

Buitenhuis, E. T., Vogt, M., Moriarty, R., Bednaršek, N., Doney, S. C., Leblanc, K., Le Quéré, C., Luo, Y. W., O'Brien, C., O'Brien, T., Peloquin, J., Schiebel, R., Swan, C., 2013. MAREDAT: towards a world atlas of MARine Ecosystem DATa. Earth System Science Data 5, 227-239.

Burd, A. and Jackson, G., 2009. Particle aggregation, Annual Review of Marine Science 1, 65-90, DOI: 10.116/annurev.marine.010908.163904.

Cardinal, D., Dehairs, F., Cattaldo, T., André, L., 2001. Geochemistry of suspended particles in the Subantarctic and Polar Frontal Zones south of Australia: Constraints on export and advection processes. Journal of Geophysical ResearchOceans 106(C12), 31637-31656.

Casciotti, K. L., Trull, T. W., Glover, D.M., Davies, D., 2008. Constraints on nitrogen cycling at the subtropical North Pacific Station ALOHA from isotopic measurements of nitrate and particulate nitrogen. Deep-Sea Research Part IITopical Studies in Oceanography 55(14-15), 1661-1672.

Chase, Z., Anderson, R. F., Fleisher, M. Q., Kubik, P. W., 2002. The influence of particle composition and particle flux on scavenging of Th, $\mathrm{Pa}$ and $\mathrm{Be}$ in the ocean. Earth and Planetary Science Letters 204(1-2), 215-229.

Chavagnac, V., Lair, M., Milton, J. A., Lloyd, A., Croudace, I. W., Palmer, M. R., Green, D. R. H., Cherkashev, G. A., 2008. Tracing dust input to the Mid-Atlantic Ridge between 14 degrees $45^{\prime} \mathrm{N}$ and 36 degrees 14 ' $\mathrm{N}$ : Geochemical and $\mathrm{Sr}$ isotope study. Marine Geology 247(3-4), 208-225.

Clegg, S. L., Whitfield M., 1990. A generalized model for the scavenging of trace metals in the open ocean, I, Particle cycling. Deep Sea Research 37, 809-832, 1990.

Clegg, S. L., Whitfield M., 1991. A generalized model for the scavenging of trace metals in the open ocean, II, Thorium scavenging. Deep-Sea Research 38, 91-120.

Cochran, J. K., Buesseler, K. O., Bacon, M. P., Livingston, H. D., 1993. Thorium isotopes as indicators of particle dynamics in the upper ocean: results from the JGOFS North Atlantic Bloom Experiment. Deep Sea Research Part I: Oceanographic Research Papers 40, 1569-1595.

Cochran, J. K., Miquel, J. C., Armstrong, R., Fowler, S. W., Masqué, P., Gasser, B., Hirschberg, D., Szlosek, J., Baena, A., Verdeny, E., Stewart, G. M., 2009. Timeseries measurements of ${ }^{234}$ Th in water column and sediment trap samples from the northwestern Mediterranean Sea. Deep-Sea Research Part II-Topical Studies in Oceanography 56(18), 1487-1501. 
Coppola, L., Roy-Barman, M., Mulsow, S., Povinec, P., Jeandel, C., 2006. Thorium isotopes as tracers of particle dynamics and deep water circulation in the Indian sector of the Southern Ocean (ANTARES IV). Marine Chemistry 100(3-4), 299313.

Craig, H., Krishnaswami, S., Somayajulu, B.L.K., $1973 .{ }^{210} \mathrm{~Pb}-{ }^{226}$ Ra radioactive disequilibrium in the deep-sea. Earth and Planetary Science Letters 17, 295-305.

Craig, H., Turekian, K. K., 1976. The GEOSECS program 1973-1976. Earth and Planetary Science Letters 32, 217.

Dehairs, F., Baeyens, W., Goeyens, L., 1992. Accumulation of suspended barite at mesopelagic depths and export production in the Southern Ocean. Science 258, 1332-1335.

Dehairs, F., Goeyens, L., Strootbans, N., Bernard, P., Goyet, C., Poisson, A., Chesselet, R., 1990. On suspended barite and the oxygen minimum in the Southern Ocean. Global Biogeochemical Cycles 4, 85-102.

Dehairs, F., Jacquet, S., Savoye, N., Van Mooy, B. A. S., Buesseler, K. O., Bishop, J. K. B., Lamborg, C. H., Elskens, M., Baeyens, W., Boyd, P. W., Casciotti, K. L., Monnin, C., 2008. Barium in twilight zone suspended matter as a potential proxy for particulate organic carbon remineralization: Results for the North Pacific. Deep-Sea Research Part II-Topical Studies in Oceanography 55(14-15), 16731683.

Dehairs, F., Jeandel, C., Miquel, J-C., Shopova, D., Ménard, S., Maguet, D., 1995. Seasonal evolution of export production and mesopelagic organic matter mineralization at station KERFIX in the Southern Ocean. In Carbon Fluxes and Dynamic Processes in the Southern Ocean: Present and Past, Southern OceanJGOFS International Symposium., Brest (Fr), 28-31 August 1995.

Dehairs, F., Shopova, D., Ober, S., Veth, C., Goeyens, L., 1997. Particulate barium stocks and oxygen consumption in the Southern Ocean mesopelagic water column during spring and early summer: Relationship with export production. Deep-Sea Research Part II-Topical Studies in Oceanography 44, 497-516.

Dehairs, F., Stroobants, N., Goeyens, L., 1991. Suspended barite as a tracer of biological activity in the Southern Ocean. Marine Chemistry 35, 399-410.

Diekmann, B., Fütterer, D. K., Grobe, H., Hillenbrand, C.-D., Kuhn, G., Michels, K., Petschik, R., Pirrung, M., 2004. Terrigenous sediment supply in the polar to temperate South Atlantic: land-ocean links of environmental changes during the late Quaternary. in: Wefer, G., Mulitza, S., Ratmeyer, V. (Eds.), The South Atlantic during the Late Quaternary: Reconstruction of Material Budget and Current Systems. Springer, Berlin, Heidelberg. Springer, Berlin, Heidelberg, pp. 375-399.

Dutay, J. C., Lacan, F., Roy-Barman, M., Bopp, L., 2009. Influence of particle size and type on ${ }^{231} \mathrm{~Pa}$ and ${ }^{230} \mathrm{Th}$ simulation with a global coupled biogeochemical-ocean general circulation model: A first approach. Geochemistry Geophysics Geosystems 10, Q01011.

Dutay, J-C., Tagliabue, A., Kriest, I., van Hulten, M.M.P., this issue. Large scale modelling of oceanic trace elements distribution. Progress in Oceanography.

Fasham, M. J. R., Balino, B. M., Bowles, M. C., Anderson, R.F., Archer, D., Bathmann, U., Boyd, P., Buesseler, K., Burkill, P., Bychkov, A., Carlson, C., Chen, C. T. A., 
Doney, S., Ducklow, H., Emerson, S., Feely, R., Feldman, G., Garçon, V., Hansell, D., Hanson, R., Harrison, P., Honjo, S., Jeandel, C., Karl, D., Le Borgne, R., Liu, K. K., Lochte, K., Louanchi, F., Lowry, R., Michaels, A., Monfray, P., Murray, J., Oschlies, A., Platt, T., Priddle, J., Quinones, R., Ruiz-Pino, D., Saino, T., Sakshaug, E., Shimmield, G., Smith, S., Smith, W., Takahashi, T., Treguer, P., Wallace, D., Wanninkhof, R., Watson, A., Willebrand, J., Wong, C. S., 2001. A new vision of ocean biogeochemistry after a decade of the Joint Global Ocean Flux Study (JGOFS). Ambio, 4-31.

Feely, R. A., Baker, E. T., Marumo, K., Urabe, T., Ishibashi, J., Gendron, J., Lebon, G. T., Okamura, K., 1996. Hydrothermal plume particles and dissolved phosphate over the superfast-spreading southern East Pacific Rise. Geochimica et Cosmochimica Acta 60, 2297-2323.

Fowler, S. W., Knauer, G. A., 1986. Role of large particles in the transport of elements and organic compound through the oceanic water column. Progress in Oceanography 16, 147-194.

François, R., Honjo, S., Krishfield, R., Manganini, S. J., 2002. Factors controlling the flux of organic carbon to the bathypelagic zone of the ocean. Global Biogeochemical Cycles 16, 1087-1106.

Frew, R. D., Hutchins, D. A., Nodder, S., Sanudo-Wilhelmy, S., Tovar-Sanchez, A., Leblanc, K., Hare, C. E., Boyd, P. W., 2006. Particulate iron dynamics during FeCycle in subantarctic waters southeast of New Zealand. Global Biogeochemical Cycles 20, GB1S93.

Garcia Solsona E., Jeandel C., Labatut M., Lacan F. and Vance D., 2014. Rare Earth Elements and $\mathrm{Nd}$ isotopes tracing water mass mixing and particle-seawater interactions in the SE Atlantic, Geochimica et Cosmochimica Acta 125, 351-372, http://dx.doi.org/10.1016/j.gca.2013.10.009.

Gardner, W.D., Richardson, M.J., Hinga, K.R., Biscaye, P.E., 1983. Resuspension measured with sediment traps in a high-energy environment. Earth and Planetary Science Letters, 66, 262-278, http://dx.doi.org/10.1016/0012-821X(83)90140-1.

Gehlen, M., Bopp, L., Ernprin, N., Aumont, O., Heinze, C., Raguencau, O., 2006. Reconciling surface ocean productivity, export fluxes and sediment composition in a global biogeochemical ocean model. Biogeosciences 3, 521-537.

Gehlen, M., Heinze, C., Maier-Reimer, E., Measures, C. I., 2003. Coupled Al-Si geochemistry in an ocean general circulation model: A tool for the validation of oceanic dust deposition fields? Global Biogeochemical Cycles 17, GB1028.

Geibert, W., Usbeck, R., 2004. Adsorption of thorium and protactinium onto different particle types: Experimental findings. Geochimica et Cosmochimica Acta 68, 1489-1501.

German, C. R., Bourles, D. L., Brown, E. T., Hergt, J., Colley, S., Higgs, N. C., Ludford, E. M., Nelsen, T. A., Feely, R. A., Raisbeck, G., Yiou, F., 1997. Hydrothermal scavenging on the Juan de Fuca Ridge: ${ }^{230} \mathrm{Th}(\mathrm{xs}),{ }^{10} \mathrm{Be}$, and REEs in ridge-flank sediments. Geochimica et Cosmochimica Acta 61, 4067-4078.

Goldberg, E. D., 1954. Marine Geochemistry 1: Chemical scavengers of the sea. Journal of Geology 62, 249-265.

Griffin, J.J., Windom, H., Goldberg, E.D., 1968. The distribution of clay minerals in the world ocean, Deep-Sea Research 15, 433-459. 
Griffith, D.R., McNichol, A.P., Xu L., McLaughlin, F.A., Macdonald , R.W., Brown, K.A., Eglinton, T.I., 2012. Carbon dynamics in the western Arctic Ocean: insights from full-depth carbon isotope profiles of DIC, DOC, and POC. Biogeosciences, 9, 1217-1224.

Guidi, L., Stemmann, L., Jackson, G. A., Ibanez, F., Claustre, H., Legendre, L., Picheral, M., Gorsky, G., 2009. Effects of phytoplankton community on production, size and export of large aggregates: A world-ocean analysis. Limnology and Oceanography 54, 1951-1963.

Hall, I. R., Schmidt, S., McCave, I. N., Reyss, J.-L., 2000. Particulate matter distribution and ${ }^{234} \mathrm{Th} /{ }^{238} \mathrm{U}$ disequilibrium along the Northern Iberian Margin: implications for particulate organic carbon export. Deep Sea Research Part I: Oceanographic Research Papers 47, 557-582.

Henderson, G. M., Maier-Reimer, E., 2002. Advection and removal of ${ }^{210} \mathrm{~Pb}$ and stable $\mathrm{Pb}$ isotopes in the oceans: A general circulation model study. Geochimica et Cosmochimica Acta 66, 257-272.

Ho, T. Y., Chou, W. C., Lin, H. L., Sheu, D. D., 2011. Trace metal cycling in the deep water of the South China Sea: The composition, sources, and fluxes of sinking particles. Limnology and Oceanography 56, 1225-1243.

Ho, T. Y., Chou, W. C., Wei, C. L., Lin, F. J., Wong, G. T. F., Lin, H. L., 2010. Trace metal cycling in the surface water of the South China Sea: Vertical fluxes, composition, and sources. Limnology and Oceanography 55, 1807-1820.

Honda, M. C., Watanabe, S., 2010. Importance of biogenic opal as ballast of particulate organic carbon (POC) transport and existence of mineral ballast-associated and residual POC in the Western Pacific Subarctic Gyre. Geophysical Research Letters 37, L02605.

Honeyman, B. D., Balistrieri, L. S., Murray, J. W., 1988. Oceanic trace metal scavenging: the importance of particle concentration. Deep-Sea Research Part II-Topical Studies in Oceanography 35, 227-246.

Honeyman, B. D. and Santschi, P. H., 1989. A Brownian-pumping model for oceanic trace metal scavenging: evidence from Th isotopes. Journal of Marine Research, 47, 951-992.

Honjo, S., 1976. Coccoliths: production, transportation and sedimentation. Marine Micropaleontology 1, 65-79.

Honjo, S., 1978. Sedimentation of materials in the Sargasso Sea at a 5,367m deep station. Journal of Marine Research 36, 469-492

Honjo, S., Krishfield, R. A., Eglinton, T. I., Manganini, S. J., Kemp, J. N., Doherty, K., Hwang, J., McKee, T. K., Takizawa, T., 2010. Biological pump processes in the cryopelagic and hemipelagic Arctic Ocean: Canada Basin and Chukchi Rise. Progress in Oceanography 85, 137-170.

Honjo, S., Manganini, S. J., Krishfield, R. A., François, R., 2008. Particulate organic carbon fluxes to the ocean interior and factors controlling the biological pump: A synthesis of global sediment trap programs since 1983. Progress in Oceanography 76, 217-285.

Honjo, S., Eglinton, T.I., Taylor C.D., Ulmer, K.M., Sievert, S.M., Bracher, A. , German, C.R., Edgcomb, V., François, R., Iglesias-Rodriguez, M.D., van Mooy, B., Repeta, D.J. , 2014. Understanding the role of the biological pump in the global 
carbon cycle: An imperative for ocean science, Oceanography, 27, 10-16, http://dx.doi.org/10.5670/oceanog.2014.78.

Huang, S., Conte, M. H., 2009. Source/process apportionment of major and trace elements in sinking particles in the Sargasso Sea. Geochimica et Cosmochimica Acta 73, 65-90.

Jackson, G.A. and Burd, A.B., this issue. Simulating particle dynamics in ocean biogeochemical models. Progress in Oceanography.

Jacquet, S. H. M., Savoye, N., Dehairs, F., Strass, V. H., Cardinal, D., 2008. Mesopelagic carbon remineralization during the European iron fertilization experiment. Global Biogeochemical Cycles 22, GB1023.

Jeandel, C., Bishop, J. K., Zindler, A., 1995. Exchange of Neodymium and its isotopes between seawater and small and large particles in the Sargasso Sea. Geochimica et Cosmochimica Acta, 59, 535-547.

Jeandel, C., Tachikawa, K., Bory, A., Dehairs, F., 2000. Biogenic barium in suspended and trapped material as a tracer of export production in the tropical NE Atlantic (EUMELI sites). Marine Chemistry 71, 125-142.

Jeandel C., Peucker-Ehrenbrink B., Jones M., Pearce C., Oelkers E., Godderis Y., Lacan F., Aumont O. and Arsouze T., 2011. Ocean margins: the missing term for oceanic element budgets? EOS transactions American Geophysical Union 92, 26.

Jickells, T. D., An, Z. S., Andersen, K. K., Baker, A. R., Bergametti, G., Brooks, N., Cao, J. J., Boyd, P. W., Duce, R. A., Hunter, K. A., Kawahata, H., Kubilay, N., La Roche, J., Liss, P. S., Mahowald, N., Prospero, J. M., Ridgwell, A. J., Tegen, I., Torres, R., 2005. Global iron connections between desert dust, ocean biogeochemistry, and climate. Science 308, 67-71.

Johnson, K. S., 2001. Iron supply and demand in the upper ocean: Is extraterrestrial dust a significant source of bioavailable iron? Global Biogeochemical Cycles 15, 6163.

Karakas, G., Nowald, N., Blaas, M., Marchesiello, P., Frickenhaus, S., Schlitzer, R., 2006. High-resolution modeling of sediment erosion and particle transport across the northwest African shelf. Journal of Geophysical Research 111, C06025.

Karakas, G., Nowald, N., Schäfer-Neth, C., Iversen, M., Barkmann, W., Fischer, G., Marchesiello, P., Schlitzer, R., 2009. Impact of particle aggregation on vertical fluxes of organic matter. Progress in Oceanography 83, 331-341.

Klaas, C., Archer, D. E., 2002. Association of sinking organic matter with various types of mineral ballast in the deep sea: Implications for the rain ratio. Global Biogeochemical Cycles 16, 63-1-63-14.

Knauer, G. A., Martin, J. H., Bruland, K. W., 1979. Fluxes of Particulate Carbon, Nitrogen, and Phosphorus in the Upper Water Column of the Northeast Pacific. Deep-Sea Research Part A: Oceanographic Research Papers 26, 97-108.

Kretschmer, S., Geibert, W., Rutgers van der Loeff, M., Mollenhauer, G., 2010. Grain size effects on ${ }^{230}$ Thxs inventories in opal-rich and carbonate-rich marine sediments. Earth and Planetary Science Letters 294, 131-142.

Kretschmer, S., Geibert, W., Rutgers van der Loeff, M. M., Schnabel, C., Xu, S., Mollenhauer, G., 2011. Fractionation of ${ }^{230} \mathrm{Th},{ }^{231} \mathrm{~Pa}$, and ${ }^{10} \mathrm{Be}$ induced by particle size and composition within an opal-rich sediment of the Atlantic Southern Ocean. Geochimica et Cosmochimica Acta 75, 6971-6987. 
Krishnaswami, S., Lal, D., Somayajulu, B. L. K., 1976a. Investigation of gram quantities of Atlantic and Pacific surface particulates. Earth and Planetary Science Letter 32, 403-419.

Krishnaswami, S., Lal, D., Somayajulu, B.L.K., Weiss, R.F., Craig, H., 1976b. Largevolume in-situ filtration of deep Pacific waters: mineralogical and radioisotope studies. Earth and Planetary Science Letters 32, 420- 429.

Kumar, N., Anderson, R.F. and Biscaye, P.E., 1996. Remineralization of particulate authigenic trace metals in the Middle Atlantic Bight: Implications for proxies of export production. Geochimica et Cosmochimica Acta 60(18): 3383-3397.

Kuss, J., Garbe-Schönberg, C. D., Kremling, K., 2001. Rare Earth Elements in suspended particulate material of North Atlantic surface waters. Geochimica et Cosmochimica Acta 65, 187-199.

Kuss, J., Kremling, K., 1999. Particulate trace element fluxes in the deep Northeast Atlantic Ocean. Deep-Sea Research Part I-Oceanographic Research Papers 46, 149-169.

Lacan, F., Jeandel, C., 2005. Neodymium isotopes as a new tool for quantifying exchange fluxes at the continent - ocean interface. Earth and Planetary Science Letters, 232, 245-257, doi:10.1016/j.epsl.2005.01.004 .

Lal, D., 1977. The oceanic microcosm of particles. Science 198, 997-1009.

Lal, D., 1980. Comments on some aspects of particulate transport in the oceans. Earth and Planetary Science Letters 49, 520.

Lam, P.J., Bishop, J.K.B., 2007. High Biomass Low Export regimes in the Southern Ocean. Deep Sea Research Part II: Topical Studies in Oceanography, 54, 601638.

Lam, P. J., Bishop, J. K. B., 2008. The continental margin is a key source of iron to the HNLC North Pacific Ocean. Geophysical Research Letters 35, L07608.

Lam, P. J., Doney, S. C., Bishop, J. K. B., 2011. The dynamic ocean biological pump: Insights from a global compilation of particulate organic carbon, $\mathrm{CaCO} 3$, and opal concentration profiles from the mesopelagic. Global Biogeochemical Cycles 25, GB3009.

Lam, P.J., Twining, B.S., Jeandel, C., Roychoudhury, A., Resing, J., Santschi, P., Anderson, R.F., this issue. Methods for analyzing the concentration and speciation of major and trace elements in marine particles. Progress in Oceanography.

Lamborg, C. H., Buesseler, K. O., Lam, P. J., 2008. Sinking fluxes of minor and trace elements in the North Pacific Ocean measured during the VERTIGO program. Deep-Sea Research Part II-Topical Studies in Oceanography 55, 1564-1577.

Lanci, L., D. V. Kent, P. E. Biscaye, and J. P. Steffensen, 2004. Magnetization of Greenland ice and its relationship with dust content, Journal of Geophysical Research 109, D09104, doi:10.1029/2003JD004433.

Lanci L., Kent D. V., Biscaye P.E., Meteoric smoke concentration in the Vostok ice core estimated from superparamagnetic relaxation and some consequences for estimates of earth accretion rate, 2007. Geophysical Research Letters 34, L10803, doi:10.1029/2007GL029811.

Landing, W. M., Bruland, K. W., 1987. The contrasting biogeochemistry of iron and manganese in the Pacific Ocean. Geochimica et Cosmochimica Acta 51, 29-43. 
Lee, S. H., Povinec, P., Gastaud, J., Oregioni, B., Coppola, L., Jeandel, C., 2009. Radionuclides as tracers of water fronts in the South Indian Ocean-ANTARES IV Results. Journal of Oceanography 65, 397-406.

Lilley, M. D., Butterfield, D. A., Olson, E. J., Lupton, J. E., Macko, S. A., McDuff, R. E., 1993. Anomalous $\mathrm{CH}_{4}$ and $\mathrm{NH}_{4}{ }^{+}$Concentrations at an Unsedimented Mid-OceanRidge Hydrothermal System. Nature 364(6432), 45-47.

Lomas, M. W., Steinberg, D. K., Dickey, T., Carlson, C. A., Nelson, N. B., Condon, R. H., Bates, N. R., 2010. Increased ocean carbon export in the Sargasso Sea linked to climate variability is countered by its enhanced mesopelagic attenuation. Biogeosciences 7, 57-70.

Lourey, M. J., Trull, T. W., Tilbrook, B., 2004. Sensitivity of delta ${ }^{13} \mathrm{C}$ of Southern Ocean suspended and sinking organic matter to temperature, nutrient utilization, and atmospheric $\mathrm{CO}_{2}$. Deep-Sea Research Part I-Oceanographic Research Papers 51, 281-305.

Luo, S. D., Ku, T. L., 2004. On the importance of opal, carbonate, and lithogenic clays in scavenging and fractionating ${ }^{230} \mathrm{Th},{ }^{231} \mathrm{~Pa}$ and ${ }^{10} \mathrm{Be}$ in the ocean. Earth and Planetary Science Letters 220, 201-211.

Lutz, M. J., Caldeira, K., Dunbar, R. B., Behrenfeld, M. J., 2007. Seasonal rhythms of net primary production and particulate organic carbon flux to depth describe the efficiency of biological pump in the global ocean. Journal of Geophysical Research 112, C10011.

McCave, I.N., 1975. Vertical flux of particles in the ocean. Deep-Sea Res., 22, 491-502.

McCave, I. N., 1984. Size spectra and aggregation of suspended particles in the deep ocean. Deep-Sea Research Part a-Oceanographic Research Papers 31, 329-352.

McCave, I. N., 1986. Local and global aspects of the bottom nepheloid layers in the world ocean. Netherlands Journal of Sea Research 20, 167- 181.

McCave, I. N., 2001. Nepheloid layers. Academic Press, London.

McDonnell, A. M. P., Buesseler, K. O., 2010. Variability in the average sinking velocities of marine particles. Limnology and Oceanography 55, 2085-2096.

McDonnell, A. M. P., Lam, P., Lamborg, C. H., Buesseler, K., Sanders, R., Riley, J. S., Marsayd, C., Smith, H. E. K., Sargent, E. C., Lampitt, R., Bishop, J. K. B., this issue. The oceanographic toolbox for the collection of sinking and suspended marine particles. Progress in Oceanography.

Michard, A., Albarède, F., Michard, G., Minster, J. F., Charlou, J. L., 1983. Rare-Earth Elements and uranium in high-temperature solutions from East Pacific Rise hydrothermal vent field $\left(13^{\circ} \mathrm{N}\right)$. Nature $303,795-797$.

Miquel, J.-C., Martin, J., Gasser, B., Baena, A. R. Y., Toubal, T., Fowler, S. W., 2011. Dynamics of particle flux and carbon export in the northwestern Mediterranean Sea: A two decade time-series study at the DYFAMED site. Progress in Oceanography 91, 461-481

Moffett, J. W., Ho, J., 1996. Oxidation of cobalt and manganese in seawater via a common microbially catalyzed pathway. Geochimica et Cosmochimica Acta 60, 3415-3424.

Mollenhauer, G., Eglinton, T. I., Ohkuchi, N., Schneider, R. R., Muller, P. J., Grootes, P. M., Rullkotter, J., 2003. Asynchronous alkenone and foraminifera records from 
the Benguela Upwelling System. Geochimica et Cosmochimica Acta 67, 21572171.

Mollenhauer, G., Kienast, M., Lamy, F., Meggers, H., Schneider, R. R., Hayes, J. M., Eglinton, T. I., 2005. An evaluation of ${ }^{14} \mathrm{C}$ age relationships between co-occurring foraminifera, alkenones and total organic carbon in continental margin sediments. Paleoceanography 20, PA1016.

Mottl, M., McConachy, T. F., 1990. Chemical processes in buyoant hydrothermal plumes on the East Pacific Rise near 21-degrees-N. Geochimica et Cosmochimica Acta 54, 1911-1927.

Neuer, S., Ratmeyer, V., Davenport, R., Fischer, G., Wefer, G., 1997. Deep water particle flux in the Canary Island region: seasonal trends in relation to long-term satellite derived pigment data and lateral sources. Deep Sea Research Part I: Oceanographic Research Papers 44, 1451-1466.

Nozaki, Y., Horibe, Y., Tsubota, H., 1981. The water column distribution of thorium isotopes in the western North Pacific. Earth and Planetary Science Letters 54, 203-216.

Okubo, A., Obata, H., Gamo, T., Yamada, M., 2012. ${ }^{230}$ Th and ${ }^{232}$ Th distributions in midlatitudes of the North Pacific Ocean: Effect of bottom scavenging. Earth and Planetary Science Letters 339/340, 139-150.

Orians, K. J., Bruland, K. W., 1986. The biogeochemistry of aluminum in the Pacific Ocean. Earth and Planetary Science Letters 78, 397-410.

Patsch, J., Kuhn, W., Radach, G., Casiano, J. M. S., Davila, M. G., Neuer, S., Freudenthal, T., Llinas, O., 2002. Interannual variability of carbon fluxes at the north Atlantic Station ESTOC. Deep-Sea Research Part II-Topical Studies in Oceanography 49, 253-288.

Paytan, A., Kastner, M., Martin, E. E., Macdougall, J. D., Herbert, T., 1993. Marine barite as a monitor of Sr isotopic composition. Nature 366, 445-449.

Petschik, R., Kuhn, G., Gingele, F., 1996. Clay mineral distribution in surface sediments of the South Atlantic: sources, transport, and relation to oceanography. Marine Geology, 130, 203-229.

Peucker-Ehrenbrink, B., 2009. Land2Sea database of river drainage basin sizes, annual water discharges, and suspended sediment fluxes. Geochemistry Geophysics Geosystems 10, 1525-2027.

Rempfer, J., Stocker, T. F., Joos, F., Dutay, J. C., 2012. On the relationship between Nd isotopic composition and ocean overturning circulation in idealized freshwater discharge events. Paleoceanography 27, PA3211.

Rempfer, J., Stocker, T. F., Joos, F., Dutay, J. C., Siddall, M., 2011. Modelling Ndisotopes with a coarse resolution ocean circulation model: Sensitivities to model parameters and source/sink distributions. Geochimica et Cosmochimica Acta 75, 5927-5950.

Renault, A., Provost, C., Sennéchael, N., Barré, N., Kartavtseff, A., 2011. Two fulldepth velocity sections in the Drake Passage in 2006: Transport estimates. Deep Sea Research Part II: Topical Studies in Oceanography 58, 2572-2591.

Roy-Barman, M., Chen, J. H., Wasserburg, G. J., 1996. ${ }^{230}$ Th- $-{ }^{232}$ Th systematics in the Central Pacific Ocean: the sources and fate of thorium. Earth and Planetary Science Letters 139, 351-363. 
Roy-Barman, M., Jeandel, C., 2011. La Géochimie Marine. Vuibert Eds. Paris.

Roy-Barman, M., Jeandel, C., Souhaut, M., Rutgers van der Loeff, M. M., Voege, I., Leblond, N., Freydier, R., 2005. The influence of particle composition on thorium scavenging in the NE Atlantic Ocean (POMME experiment). Earth and Planetary Science Letters 240, 681-693.

Roy-Barman, M., Lemaitre, C., Ayrault, S., Jeandel, C., Souhaut, M., Miquel, J. C., 2009. The influence of particle composition on thorium scavenging in the Mediterranean Sea. Earth and Planetary Science Letters 286, 526-534.

Rudnicki, M. D., Elderfield, H., 1993. A chemical-model of the buoyant and neutrally buoyant plume above the Tag Vent Field, 26 Degrees-N, Mid-Atlantic Ridge. Geochimica et Cosmochimica Acta, 57, 2939-2957.

Rutgers van der Loeff, M. M., Berger, G., W., 1993. Scavenging of ${ }^{230}$ Th and ${ }^{231} \mathrm{~Pa}$ near the Antarctic Polar Front in the South Atlantic. Deep-Sea Research Part IOceanographic Research Papers, 40, 339-357.

Rutgers van der Loeff, M. M., Boudreau, B. P., 1997. The effect of resuspension on chemical exchanges at the sediment water interface - A modelling and natural radiotracer approach. Journal of Marine System 11, 305-342.

Santschi, P. H., Murray, J. W., Baskaran, M., Benitez-Nelson, C. R., Guo, L. D., Hung, C.-C., Lamborg, C., Moran, S. B., Passow, U., Roy-Barman, M., 2006. Thorium speciation in seawater. Marine Chemistry 100, 250-268.

Sarin, M. M., Krishnaswami, S., Dalai, T. K., Ramaswamy, V., Ittekkot, V., 2000. Settling fluxes of U- and Th-series nuclides in the Bay of Bengal: results from time-series sediment trap studies. Deep-Sea Research Part I-Oceanographic Research Papers 47(10), 1961-1985.

Sarmiento, J. L., Feely, H. W., Moore, W. S., Bainbridge, A., 1976. The relationship between vertical eddy diffusion and buoyancy gradient in the deep sea. Earth and Planetary Science Letters 32, 357-370.

Scholten, J. C., Fietzke, J., Vogler, S., Rutgers van der Loeff, M. M., Mangini, A., Koeve, W., Stoffers, P., Antia, A., Neuer, S., Waniek, J. J., 2001. Trapping efficiencies of sediment traps from the deep eastern North Atlantic: The ${ }^{230} \mathrm{Th}$ calibration. Deep Sea Research Part II: Topical Studies in oceanography. JGOFS North Atlantic Synthesis 48, 2383-2408.

Shanks, A.L. , Trent, J.D., 1980. Marine snow - sinking rates and potential role in vertical flux. Deep-Sea Research 27, 137-143.

Sherrell, R. M., Boyle, E. A., 1992. The trace-metal composition of suspended Particles in the Oceanic Water Column near Bermuda. Earth and Planetary Science Letters 111, 155-174.

Sherrell, R. M., Field, M. P., Gao, Y., 1998. Temporal variability of suspended mass and composition in the Northeast Pacific water column: relationships to sinking flux and lateral advection. Deep-Sea Research Part II-Topical Studies in Oceanography 45, 733-761.

Sherrell, R. M., Field, P., Ravizza, G., 2000. Uptake and fractionation of Rare Earth Elements on hydrothermal plume particles at $9^{\circ} 45^{\prime} \mathrm{N}$, East Pacific Rise. Geochimica et Cosmochimica Acta 63, 1709-1722.

Steinberg, D. K., Cope, J., Wilson, S., Kobari, T., 2008. A comparison of mesopelagic mesozooplankton community structure in the subtropical and subarctic North 
1053

1054

1055

1056

1057

1058

1059

1060

1061

1062

1063

1064

1065

1066

1067

1068

1069

1070

1071

1072

1073
Pacific Ocean. Deep Sea Research Part II- Topical Studies in Oceanography 55, 1615-1635.

Sternberg, E., Jeandel, C., Robin, E., Souhaut, M., 2008. Seasonal cycle of suspended barite in the Mediterranean Sea. Geochimica et Cosmochimica Acta 72, 40204034.

Stewart, G., Cochran, J. K., Miquel, J. C., Masque, P., Szlosek, J., Baena, A., Fowler, S. W., Gasser, B., Hirschberg, D. J., 2007. Comparing POC export from ${ }^{234} \mathrm{Th} /{ }^{238} \mathrm{U}$ and ${ }^{210} \mathrm{Po} /{ }^{210} \mathrm{~Pb}$ disequilibria with estimates from sediment traps in the northwest Mediterranean. Deep-Sea Research Part I-Oceanographic Research Papers 54, 1549-1570.

Sylvan, J. B., Pyenson, B. C., Rouxel, O., German, C. R., Edwards, K. J., 2012. Timeseries analysis of two hydrothermal plumes at 9 degrees 50'N East Pacific Rise reveals distinct, heterogeneous bacterial populations. Geobiology 10, 178-192.

Tachikawa, K., Jeandel, C., Dupre, B., 1997. Distribution of Rare Earth Elements and neodymium isotopes in settling particulate material of the Tropical Atlantic Ocean (EUMELI site). Deep-Sea Research Part I-Oceanographic Research Papers 44, 1769-1792.

Tachikawa, K., Jeandel, C., Roy-Barman, M., 1999a. A new approach to the Nd residence time in the ocean: the role of atmospheric inputs. Earth and Planetary Science Letters 170, 433-446.

Tachikawa, K., Jeandel, C., Vangriesheim, A., Dupré, B., 1999b. Distribution of Rare Earth Elements and neodymium isotopes in suspended particles of the tropical Atlantic Ocean (EUMELI site). Deep-Sea Research Part I-Oceanographic Research Papers 46, 733-755.

Tachikawa, K., Roy-Barman, M., Michard, A., Thouron, D., Yeghicheyan, D., Jeandel, C., 2004. Neodymium isotopes in the Mediterranean Sea: Comparison between seawater and sediment signals. Geochimica et Cosmochimica Acta 68, 30953106.

Tagliabue, A., Bopp, L., Dutay, J. C., Bowie, A. R., Chever, F., Jean-Baptiste, P., Bucciarelli, E., Lannuzel, D., Remenyi, T., Sarthou, G., Aumont, O., Gehlen, M., Jeandel, C., 2010. Hydrothermal contribution to the oceanic dissolved iron inventory. Nature Geoscience 3, 252-256.

Toner, B. M., Fakra, S. C., Manganini, S. J., Santelli, C. M., Marcus, M. A., Moffett, J., Rouxel, O., German, C. R., Edwards, K. J., 2009. Preservation of iron(II) by carbon-rich matrices in a hydrothermal plume. Nature Geoscience 2, 197-201.

Trull, T. W., Bray, S. G., Buesseler, K. O., Lamborg, C. H., Manganini, S., Moy, C., Valdes, J., 2008. In situ measurement of mesopelagic particle sinking rates and the control of carbon transfer to the ocean interior during the Vertical Flux in the Global Ocean (VERTIGO) voyages in the North Pacific. Deep-Sea Research Part II-Topical Studies in Oceanography 55, 1684-1695.

Turekian, K. K., 1977. The fate of metals in the ocean. Geochimica et Cosmochimica Acta 41, 1139-1144.

Turnewitsch, R., Reyss, J.-L., Nycander, J., Waniek, J. J., Lampitt, R. S., 2008. Internal tides and sediment dynamics in the deep sea-Evidence from radioactive ${ }^{234} \mathrm{Th} /{ }^{238} \mathrm{U}$ disequilibria. Deep Sea Research Part I: Oceanographic Research Papers 55, 1727. 
1074

1075

1076

1077

1078

1079

1080

1081

1082

1083

1084

1085

1086

1087

1088

1089

1090

1091

1092

1093

1094

1095

1096

1097

1098

1099 van Beek, P., Francois, R., Conte, M., Reyss, J- L., Souhaut, M., Charette, M., 2007. ${ }^{228} \mathrm{Ra} /{ }^{226} \mathrm{Ra}$ and ${ }^{226} \mathrm{Ra} / \mathrm{Ba}$ ratios to track barite formation and transport in the water column. Geochimica et Cosmochimica Acta 71, 71-86.

van Beek, P., Sternberg, E., Reyss, J. L., Souhaut, M., Robin, E., Jeandel, C., 2009. ${ }^{228} \mathrm{Ra} /{ }^{226} \mathrm{Ra}$ and ${ }^{226} \mathrm{Ra} / \mathrm{Ba}$ ratios in the Western Mediterranean Sea: Barite formation and transport in the water column. Geochimica et Cosmochimica Acta 73, 4720-4737.

van Beek, P., Reyss, J-L., 2001. ${ }^{226}$ Ra in marine barite: new constraints on supported ${ }^{226} \mathrm{Ra}$. Earth and Planetary Science Letters 187, 147-161.

van Beek, P, Reyss, J-L, Gersonde, R., Paterne, M., Rutgers van der Loeff, M., Kuhn, G., 2002. ${ }^{226} \mathrm{Ra}$ in barite: Absolute dating of Holocene Southern Ocean sediments and reconstruction of sea-surface reservoir ages. Geology 30, 731-734.

Venchiarutti, C., Rutgers van der Loeff, M., Stimac, I., 2011. Scavenging of ${ }^{231} \mathrm{~Pa}$ and ${ }^{230} \mathrm{Th}$ isotopes based on dissolved and size-fractionated particulate distributions at Drake Passage (ANTXXIV-3). Deep-Sea Research Part II-Topical Studies in Oceanography 58, 2767-2784.

Verdugo, P., 2012. Marine microgels. Annual Review of Marine Science 4, 375-400.

Warren, B. A.,1981. Deep circulation of the world ocean, in Evolution of Physical Oceanography, B. A. Warren and C. Wunsch (eds.), the MIT Press, Cambridge, Massachusetts and London, England, pp. 6-41.

Williams, P. M., Robertson, K. J., Soutar, A., Griffin, S. M., Druffel, E. R. M., 1992. Isotopic signatures $\left({ }^{14} \mathrm{C},{ }^{13} \mathrm{C},{ }^{15} \mathrm{~N}\right)$ as tracers of sources and cycling of soluble and particulate organic-matter in the Santa-Monica Basin, California. Progress in Oceanography 30, 253-290. 
$30 / 12 / 201419: 56$

\section{$1100 \quad$ Figure Captions}

1101

1102 Figure 1

1103 Illustration of the different sources, internal cycling and sinks of oceanic particles. Reproduced

1104 from Roy-Barman and Jeandel (2011).

1105

1106 Figure 2

1107 Profiles of particulate matter concentration (PMC) at the Northern Iberian Margin $\left(43^{\circ} \mathrm{N}\right.$, June

1108 1997) calculated from beam attenuation (solid line) and light scattering (dotted line) against

1109 depth, together with the density structure $\left(\square_{t}\right)$ of the water column (dashed line). Reprinted from

1110 "Hall, I. R., Schmidt, S., McCave, I. N., Reyss, J.-L., 2000. Deep Sea Research Part I:

1111 Oceanographic Research Papers 47, 557-582. Copyright (2014), with permission from Elsevier"

1112

\section{Figure 3}

1114 Longitudinal section of the dry weight of particulate matter along the western Atlantic Ocean

1115 from the GEOSECS program. Reprinted from "Brewer, P. G., Spencer, D. W., Biscaye, $P$.

1116 E., Hanley, A., Sachs, P. L., Smith, C. L., Kadar, S., Fredericks, J., 1976. The

1117 distribution of particulate matter in the Atlantic Ocean. Earth and Planetary Science

1118 Letters 32, 393-402. Copyright (2014), with permission from Elsevier"

1119

\section{$1120 \quad$ Figure 4}

1121 Particle dynamics as depicted by thorium (Th) isotopes in the mid-80s. Th isotopes are produced

1122 in solution by radioactive decay of the soluble U or Ra isotopes. Due to their very low solubility,

1123 Th isotopes are rapidly adsorbed on small particles and colloids that represent most of the

1124 available solid surface. Th isotopes then follow the dynamics of particles. Th isotopes differ by

1125 their radioactive decay constants (lambda) and input functions. Combining the different isotopes

1126 allows determining the other time constants: $\mathrm{k}_{\mathrm{ads}}$ for adsorption, $\mathrm{k}_{\mathrm{des}}$ for desorption, $\mathrm{k}_{\mathrm{aggr}}$ for

1127 aggregation, $\mathrm{k}_{\mathrm{dis}}$ for disaggregation, as well as the sinking speeds of the different types of

1128 particles. Remineralization of large particles was neglected due to the low solubility of thorium.

1129 Colloids were not included either because their impact on Th isotopes was highlighted later

1130 (Honeyman and Santschi, 1989). The main 1-D scheme is certainly dramatically oversimplified

1131 compared to the ecosystem-driven real processes. Small particles are aggregated into large

1132 particles either by zooplankton grazing (producing fecal pellets) or by abiotic aggregation of

1133 organic and inorganic material in fluff, due to sticking exudates produced at the end of the bloom. 
1134 Large particles can scavenge and drag small ones in a sort of "oceanic piggy-back" process (Lal, 1135 1980). Large particles can also disaggregate into small particles when sinking. Indeed, the most 1136 fragile large particles, such as marine snow, can be broken by the turbulence of the current. Fecal 1137 pellets can also be destroyed by bacterial activity. The apparent settling velocity is the net effect

1138 of all these processes. The deduced particle residence time can therefore be applied to other 1139 poorly soluble TEIs. From Roy-Barman and Jeandel (2011) and redrawn from Bacon et al. 1140 (1985).

1141 
1142

Figure 1

1143

1144

1145

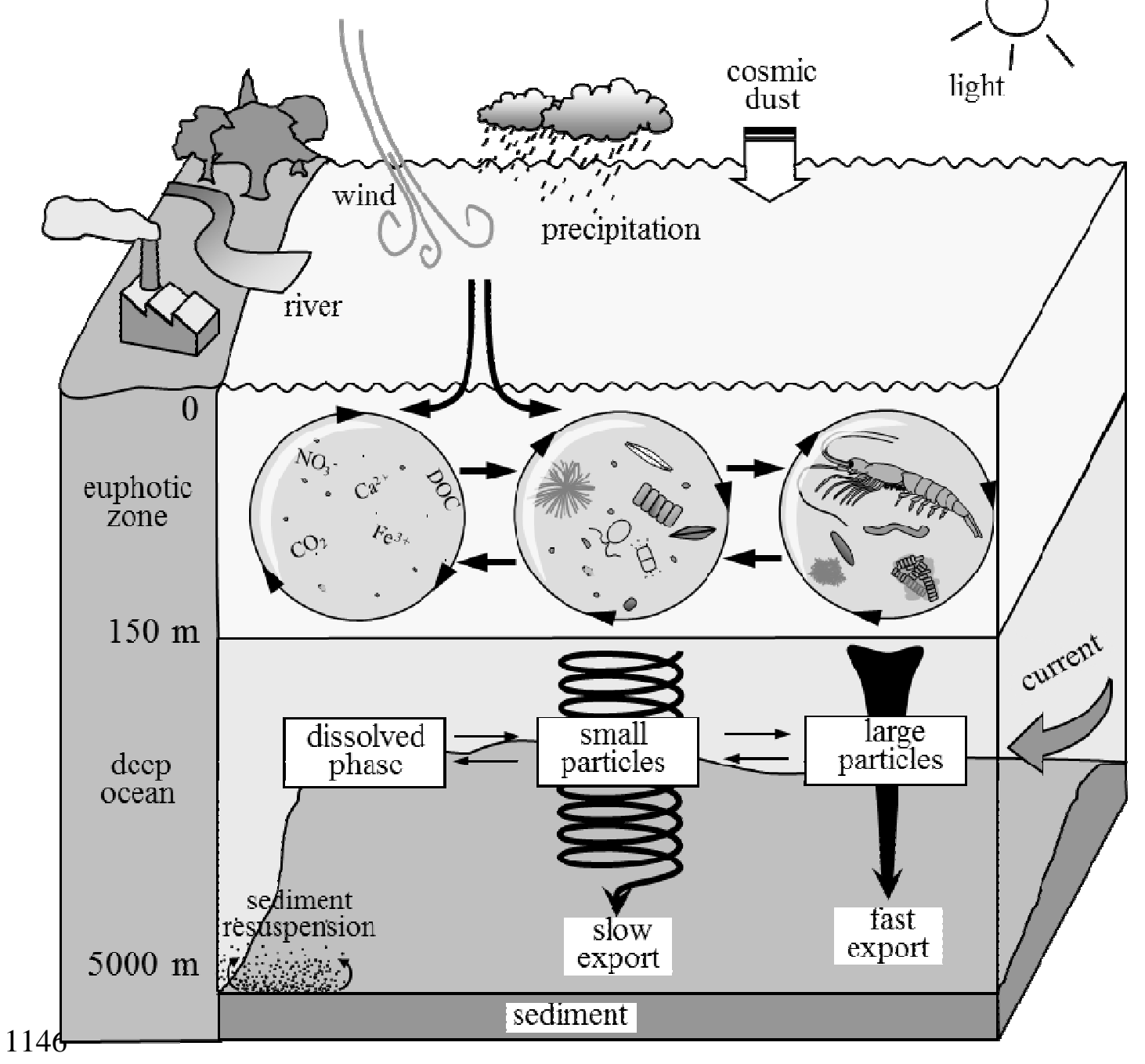


1147

1148

1149

\section{Figure 2}

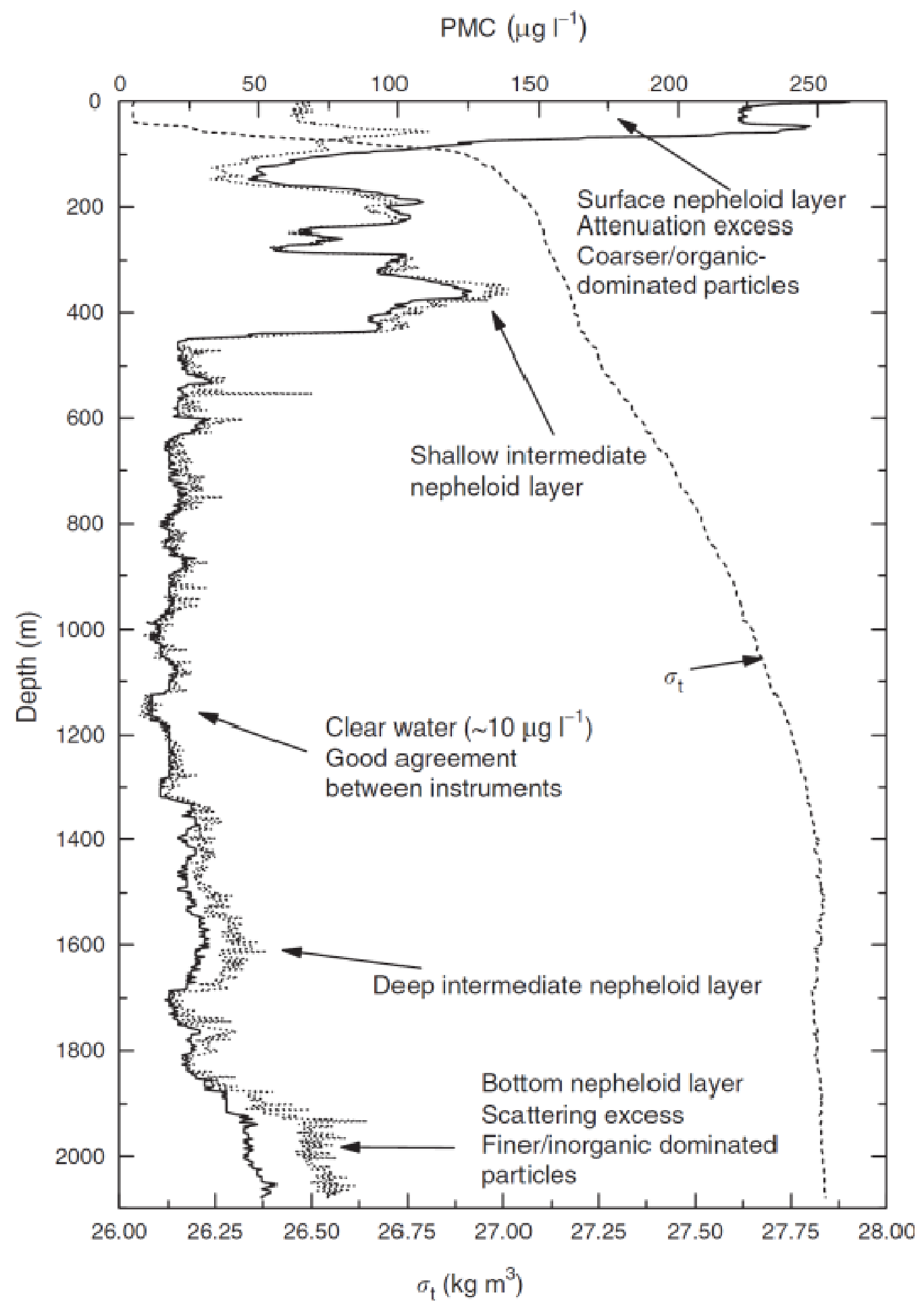


$30 / 12 / 201419: 56$

1153 Figure 3

1154

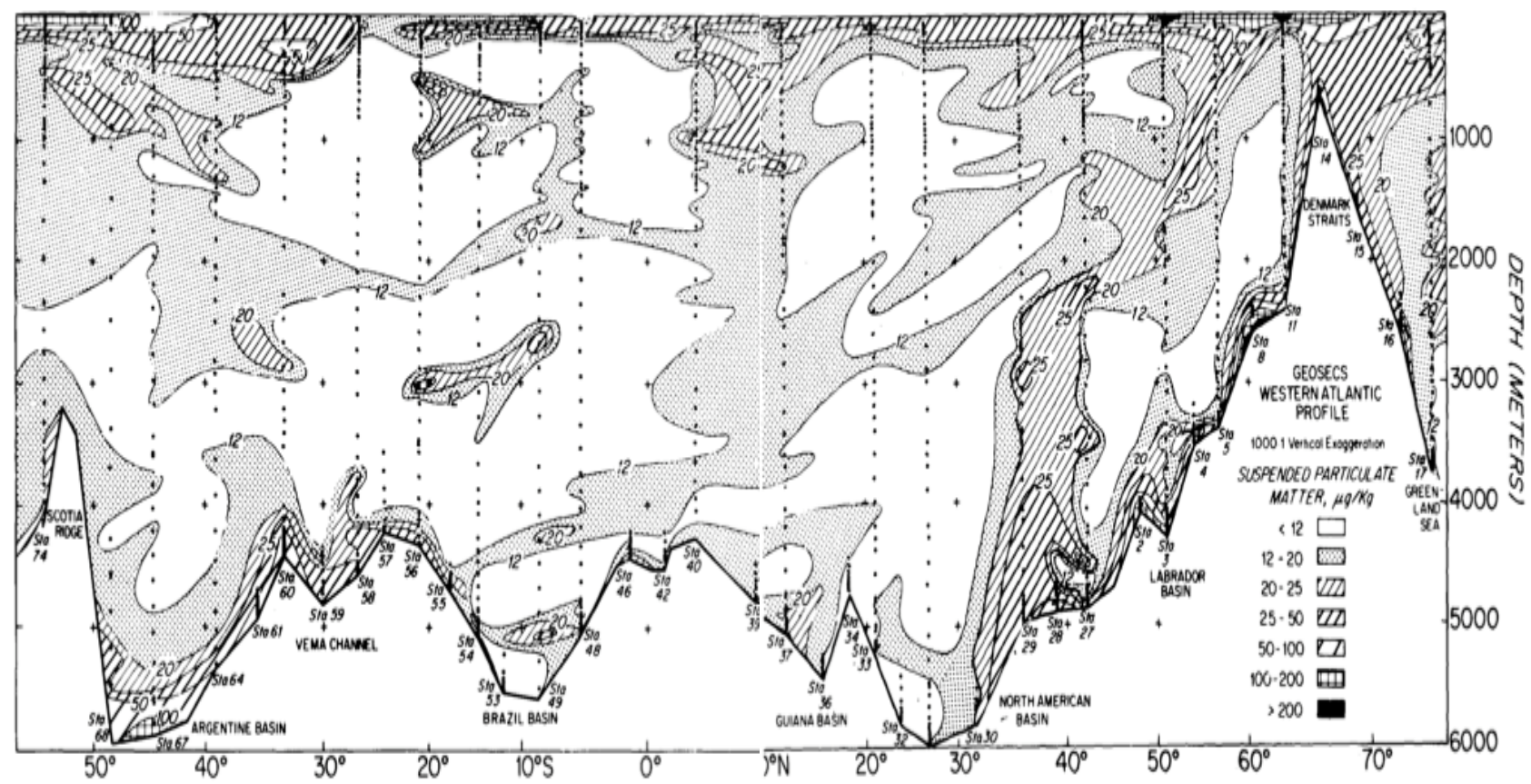

Fiq. 2. Longitudinal section of the dry weight of particulate matter in the western Atantic Ocean. 
$30 / 12 / 201419: 56$

1155

1156

Figure 4

1157

1158

1159

1160

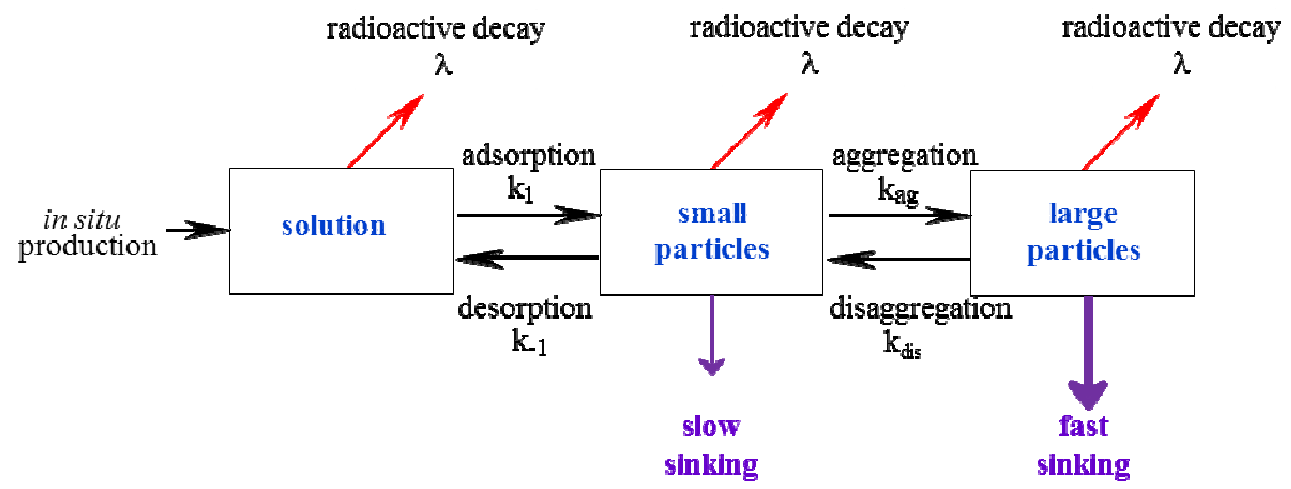

1161

1162 